\title{
The Impact of Advertising on Fund Flows in Alternative Distribution Channels
}

\author{
Jeffrey J. Yankow (Corresponding author) \\ Department of Economics, Furman University \\ 3300 Poinsett Hwy, Greenville, SC 29613, USA \\ Tel: +1-864-294-3321Ｅ-mail: jeff.yankow@furman.edu \\ Thomas I. Smythe \\ Department of Business and Accounting, Furman University \\ 3300 Poinsett Hwy, Greenville, SC 29613, USA \\ Tel: +1-864-294-3312Ｅ-mail: thomas.smythe@furman.edu \\ Vance P. Lesseig \\ Department of Finance, Texas State University at San Marcos \\ 601 University Ave, San Marcos, TX 78666, USA \\ Tel: +1-512-245-6726_E-mail: vl13@txstate.edu
}

Michael A. Jones

Department of Marketing and Entrepreneurship, University of Tennessee at Chattanooga

300 Fletcher Hall, 615 McCallie Avenue, Dept 6056, Chattanooga, TN 37403, USA

Tel:+1-423-425-1723_E-mail: Michael-jones@utc.edu

Received: December 3, 2010 Accepted: January 6, $2011 \quad$ doi:10.5430/ijfr.v2n1p2

\begin{abstract}
Existing literature demonstrates a positive relationship between advertising and subsequent mutual fund flows. While this relationship is hardly unexpected, it has only been addressed in a limited fashion. This work seeks to explore the issue in greater depth by examining both fixed income and equity funds, by separating load and no-load funds, and by using a richer empirical model. Our findings support the accepted relationship in general, but indicate that the response by investors differs between fund types (equity vs. fixed income) and the direct (no-load) and broker-sold (load) markets. Finally, we provide evidence that earlier findings are contingent upon the sample of funds selected as well as the empirical specification.
\end{abstract}

Keywords: Mutual funds, Asset flows, Fund advertising.

\section{Introduction}

Mutual fund advertising has been criticized on many fronts by both practitioners and academics (Bogle, 1999; Jain and $\mathrm{Wu}, 2000)$. Advertising has, however, been shown to impact flows to mutual funds and can thus be considered somewhat successful (Barber, Odean, and Zheng, 2005; Jain and Wu, 2000). Our paper extends the literature on asset flow in three ways, using the relationship between print advertising and fund flows as the empirical setting. First we expand the analysis of equity fund flows in earlier studies (e.g. Siri and Tufano, 1998; Jain and Wu, 2000; Barber, et al., 2002) by including funds that advertise but do not advertise performance and by including a broader sample of equity funds. Jones and Smythe (2003) find that while the propensity to advertise performance has increased over time, many funds advertise without promoting performance (Note 1). As such, the question that arises is whether it is simply advertising that attracts flows or the promotion of performance that leads to increased assets. 
Our second extension is to examine the impact of advertising on bond mutual fund flows. Research into other areas of mutual funds, such as costs (e.g. Malhotra and McLeod, 1997) and performance (e.g. Elton, Gruber, and Blake, 1996) indicate substantial differences across asset classes. Additionally, Jones, Lesseig, and Smythe (2003) demonstrate that bond funds with strong past performance are no more likely to advertise than other funds, suggesting prior performance may be less important for bond funds choosing to advertise. Thus, the relationship between advertising and fund flows found by Jain and $\mathrm{Wu}$ (2000) for domestic equity funds may be different for bond funds (Note 2).

The third contribution is to examine whether investors from the two retail distribution channels, direct-market (no-load) and broker-sold (load), respond to print advertising and other fund information in similar ways, as measured by flows to specific fund classes. This analysis is similar to that of O'Neal (2004), Shrider (2009), and Zoran and Weisbenner (2009), who examine purchase and redemption patterns of investors in these distribution channels. Jain and Wu (2000) suggest that it is the promotion of performance that leads to fund flows, but it seems unlikely that investors are so impulsive that they purchase strictly based on a fund advertising past performance. However, two experimental studies suggest otherwise. Kliger, Levy, and Sonsino (2003) demonstrate that investors allocate flows to funds with high past absolute performance. Also, Pontari, Stanaland, and Smythe (2009) find that even if other salient information (cost) is prominently displayed in an ad, investors still overwhelmingly use performance as their primary selection criteria.

Whether promoting performance or not, we hypothesize that fund advertising is an effort by fund companies to reduce investor search costs as suggested by Sirri and Tufano (1998). If so, we would expect potential investors to examine other fund information such as fund expenses and prior returns, prior to making investment decisions. We investigate this possibility, but we do so by examining whether investors in the direct-market and broker-sold channels use information in similar or different ways. Additionally, we examine whether these investor groups respond to information differently depending on whether the ad promotes performance or not.

Our findings can be summarized as follows. Advertising does work to increase fund flows, however, it works differently for equity and bond funds and appears most successful in reaching investors in the broker-sold channel, independent of whether ads promote performance or not. When employing a model similar to Jain and $\mathrm{Wu}$ (2000), we find domestic equity funds advertising performance do have higher fund flows. However, when the sample is broadened to include the specialized and international equity categories, advertising is no longer a significant determinant of asset flows. Additionally, bond funds that advertise also see higher flows. However, only four bond fund ads contained performance information, indicating that fixed-income fund investors may value other information when making the investment decision.

The conclusions regarding advertising success are sensitive to model specification. When we expand the empirical model to include a broader set of controls, advertising performance is related to increased equity fund flows for no-load funds. Equity funds that advertise to no-load investors without promoting performance, however, experience significantly lower flows. When estimating the expanded empirical model for broker-sold equity funds, advertising, without promoting performance, is related to increased flows. Finally, our results indicate advertising is related to lower bond fund flows when ads target no-load investors.

\section{Motivation}

\subsection{Equity Fund Analysis}

Earlier fund flow research focuses largely on domestic equity funds. Sirri and Tufano (1998) began work in this area by examining the well-documented asymmetric relationship between asset flows and fund performance. Investors pour money into funds with strong past performance, but exit funds more slowly after poor performance. DelGuercio and Tkac (2002a) confirm the result in their study examining the flow/performance relationship for pension and mutual funds. An interesting finding in their study is that retail investors focus more attention on past raw performance as opposed to risk-adjusted performance measures. Zoran and Weisbenner (2009) further investigate the issue and find that inflows to funds are related to relative performance (by investment objective) but redemptions are based on absolute performance. Jones, et al. (2003) find equity funds are more likely to advertise in years following strong raw performance, but not in years following strong risk-adjusted performance.

Sirri and Tufano (1998) also demonstrate that reducing search costs for consumers is important for fund companies. As such, fund marketers behave in economically rational ways when they focus on past performance in advertisements. Jain and $\mathrm{Wu}(2000)$ confirm the performance/advertisement flow relationship identified by Sirri and Tufano (1998), but they go on to show that advertisements are misleading to the extent recent superior performance is not repeated in subsequent years (Note 3). Finally, Barber, et al (2005) conclude that advertising works, similar to Jain and Wu. However, they do not measure advertising directly, but find that fund flows are higher for funds with higher $12 \mathrm{~b}-1$ fees, where $12 \mathrm{~b}-1$ fees proxy for advertising. 
Our analysis of equity funds focuses on the relationship between asset flows and advertisement; however, unlike Jain and $\mathrm{Wu}(2000)$ and others, we include funds that advertise, but do not include performance, in addition to those funds with ads specifically promoting performance. This is an important issue from the fund companies' and investors' perspective. The primary purpose of advertising (Belch and Belch, 2004) is to generate/increase product sales. The economic motivation for fund companies is clear. Fund managers generate higher fee revenue with more assets under management. However, this is an important question for investors as well, for if advertising does not increase flows, one must question its value (Note 4). Presumably, if fund boards fulfill their fiduciary role, then they also believe advertising is in the investors' best interest. As a simplifying premise, we assume interests of fund companies and investors are properly aligned and monitored by boards.

At issue is the fact that advertising is costly. In some cases, fund companies absorb the costs in management fees. As such, fund companies are interested in whether advertising achieves its intended objective. More commonly however, advertising costs are passed on to investors in the form of higher operating expenses or 12b1-fees. By only examining funds advertising performance, we ignore an important question: Does advertising, regardless of content, lead to increased asset flows, where the ads help reduce investor search costs as proposed by Sirri and Tufano (1998), or are increased flows associated exclusively with funds advertising performance? The analysis below addresses this question.

\subsection{Fixed Income Fund Analysis}

While a growing amount of research addresses the determinants of asset flows into equity funds, less emphasis has been placed on the determinants of bond fund asset flows. One likely reason for the equity focus is the outsized returns and popularity equity funds achieved during the late 1990's. Even so, the significance of fixed income funds cannot be overlooked. As of year-end 2009, approximately 28 percent of all fund assets were in bond funds, totaling over two trillion dollars (Note 5). As such, factors influencing asset flows into this asset class are important.

Prior studies examining fixed income fund asset flow determinants have done so with a very narrow focus. Christoffersen (2001) examines the impact of fee waivers on money market fund operations and finds funds using waivers for money market funds distributed to retail investors have higher flows. Atkinson, Baird, and Frye (2003) examine bond fund flow determinants as they relate to female fund managers and therefore have a limited sample. Finally, Frye (2001) examines the flow/performance relationship of bank managed versus non bank-managed bond funds. She finds that past performance is not as critical to bond flows for bank-operated funds as it is for non bank-managed funds and concludes that other bank characteristics such as reputation and reduction of search costs are more important.

Our examination of bond fund asset flows is most closely related to Frye (2001). However, we expand that analysis using a larger sample and a richer empirical model that incorporates a broader set of factors thought to influence asset flows. More importantly for our study, however, is that prior research examining the impact of advertising/media attention on fund flows (Jain and Wu, 2000; Sirri and Tufano, 1998) have not included bond funds, while research examining the determinants of bond fund flows has not examined the relationship between advertising and bond fund flows. This is an important question to address for two reasons. First, the cost of advertising has a larger proportional impact on bond funds because average returns and expense ratios are lower than for equity funds. As such, knowing whether advertising achieves the objective of increasing asset flows is relatively more important for bond than equity funds. Second, we argue that fixed income funds are a fundamentally different product and that investors utilize different information to make purchase decisions. Hence, the impact of advertising on bond fund flows may differ when compared to equity funds.

\subsection{Retail Distribution}

Prior to 1980, most funds were broker-sold. However, beginning with the creation of the Vanguard Group, the direct-market channel developed rapidly. Barber, et al. (2005) report that the proportion of direct-marketed fund assets increased from nine percent in 1962 to $65 \%$ in 1999. They attribute the increase in part to investor learning, specifically with regard to easily visible fees such as front-end loads. With the growth in the direct channel, the retail fund market can be distinctly delineated based on distribution channel.

As the separation has become more pronounced, there has been growing interest in how investors in the channels differ. Prior research uses surveys to gauge each group's level of financial knowledge and to identify primary information sources used when making fund purchase decisions. Capon, Fitzsimons, and Prince (1996) find investors using the direct channel say that they rely less on advertising and performance rankings relative to investors using commission-based financial advisors (Note 6). In addition, Alexander, Jones, and Nigro (1998) find investors using the direct-market channel have a significantly higher level of financial literacy and more knowledge about fund expenses when compared to investors using the broker-sold channel. More recently, O'Neal (2004), Shrider (2009), and Zoran and Weisbenner 
(2009) examine the relative sensitivity of investor purchases to past performance for these investor groups and finds investors in the broker-sold channel to more aggressively chase past performance.

An important difference between the two channels is the presence of the broker. While investors in the broker-sold channel appear less knowledgeable, the broker's role is to help overcome this weakness. Given the training and testing required by NASD and other regulatory bodies, it is possible investors in the broker-sold channel make better informed fund purchases. Jones, Lesseig, and Smythe (2004) find brokers use different information from investors when making fund recommendations. Brokers say they rely primarily on data sources such as Lipper and largely ignore advertising. Additionally, brokers focus on fund risk and performance relative to peers when making recommendations, in contrast to individual investors. Based on this discussion, it remains an empirical question as to whether differences exist between how no-load and load investors respond to advertising and other fund information. If brokers overcome investors' lack of knowledge in the broker-sold channel then these investors are likely to be less responsive to advertisements in general and those promoting performance specifically. There is one caveat regarding the discussion of investor type and fund flow response. Investors using fee-based financial advisors purchase some no-load funds. Although the proportion of no-load funds purchased this way is believed to be small, it may well have an impact on our ability to identify differences in the ad/fund flow response between the two markets.

\section{Data and Methodology}

\subsection{Data}

The data comes from two sources. First, individual retail mutual funds advertising in the 12 monthly issues of Money magazine during 1999 are identified and ad characteristics are recorded. Only ads from Money were chosen for two reasons. We found by examining several other periodicals that ads overlap by fund and content across publications. Second, Money was the most widely circulated personal finance periodical during 1999 (see SRDS Consumer Magazine Advertising Source 2000) (Note 7).

After identifying funds that advertise, corresponding fund characteristics are collected from Morningstar's Principia software. Multiple years of data are required to construct several variables. Contemporaneous fund characteristics such as investment objective and load structure come from year-end 2000 since we examine fund flows from year-end 1999 to year-end 2000 for funds advertising at any point in 1999. Variables such as lagged expenses, prior year performance, and prior year star ratings come from year-end 1999. This latter criterion essentially requires the funds in our sample to be at least four years old since Morningstar does not begin calculating stars until a fund has been in existence for three years.

In addition to advertised funds, we construct our control group as retail funds in the investment objective categories from which the advertised funds come. Barber, et al. (2005) finds that flows into funds in the lower 30 percent of the sample in terms of size exhibit characteristics that vary substantially from those of the largest 70 percent. This choice varies somewhat from prior studies. Both Jain and Wu (2000) and Barber, et al. (2005) conduct similar analyses with such a control group. The primary control group for Jain and $\mathrm{Wu}$, however, is made up of at most eight funds for each advertising fund. We choose the broader control group for several reasons. First, Jain and Wu argue for a control group matched on past returns because "fund performance seems to be the most important variable explaining fund flows" (p. 951). While a true statement, Jain and Wu only control for four other non-return factors in their empirical model (Note 8). Subsequent research (Frye, 2001; DelGuercio and Tkac, $2002 \mathrm{a}, \mathrm{b}$ ) and discussion below argues for a broader range of fund characteristics that impact flows and could therefore be argued as appropriate characteristics along which to construct control groups. Moreover, Jain and Wu (2000) and Barber, et al. (2005) find qualitatively similar results when using a broader control group. Given our more refined empirical model, we choose to minimize the potential for selection bias that arises when constructing control groups based on one or two characteristics and use the largest $70 \%$ of funds from the advertised investment objectives.

The second reason for using a broader control group is related to a central question addressed in this study. Unlike prior studies, we examine the impact of advertising on fund flows, whether or not the ad promotes performance. If funds that advertise, but do not promote performance, have historical returns that differ from funds that advertise performance, then matching control funds based on performance exclusively may be inappropriate.

A final point regarding data must be addressed. Beginning in 1995, fund companies have been allowed under rule 18-f of the Investment Company Act to create and distribute multiple share class (MS) funds that represent one portfolio of assets, but investors have a variety of pricing choices as to how financial advisors are compensated (see Livingston and O'Neal (1998) for a full description of MS funds). While each class is technically part of the same fund (portfolio of assets) each class is reported separately in Morningstar as if it were a separate portfolio. This is an important distinction 
for the empirical analysis. The funds that advertise include MS funds. The ad, if it identifies the fund as having more than one class, never promotes a specific class, but the portfolio as a whole. As a result, the empirical analysis assumes each class of an MS fund having an ad is in fact advertised. We feel this assumption is realistic since the intent is to attract investors to the portfolio and the choice of class is made subsequent to the portfolio choice. We handle this in the empirical analysis in two ways. First, our preferred specifications include a rich array of control variables capturing class characteristics that may differentially impact fund flows. Second, all standard errors are corrected for correlation across classes within MS funds.

Table 1 provides a description of advertising propensity across each fund category. Panel A pertains to the sample of the largest $70 \%$ of retail domestic equity funds, Panel B refers to the sample of all equity funds, and Panel C the sample of fixed income funds. Looking first at the final column of Panel A, we see that 7 percent (105 funds) of the sample of 1,500 funds advertised in Money magazine at some point during calendar year 1999. Further, of the funds that advertised, 45 percent (47 funds) advertised some aspect of performance. Thus, 3.1 percent of the domestic equity sample advertised performance. Not surprisingly, the percentage of funds advertising is quite similar for the entire sample of equity funds. In Panel B, we find that 7.1 percent (156 funds) advertised, and of these, 43 percent (67 funds) advertised past performance (or 3.1 percent of the full equity sample). Finally, as demonstrated in Panel C, bond funds are somewhat less likely to advertise when compared to either sample of equity funds. Of the 1,979 funds comprising the fixed income sample, only 6.3 percent (124 funds) advertise. Also note that only four fixed income funds advertise performance. Consequently, we do not distinguish bond funds according to whether they advertised performance or not in the ensuing analysis.

Table 1 provides a further distinction as to whether the fund is broker-sold (load) or marketed directly to consumers (no-load). In general, no-load funds are more likely to advertise than broker-sold funds, and are more likely to advertise performance. In the sample of domestic equity funds, 9.1 percent of no-load funds advertise whereas only 4.9 percent of the load funds do so. Of the funds that advertised, 48 percent in the direct-market channel advertised performance whereas only 39 percent of the broker-sold funds did so. In the full sample of equity funds, the advertising figures are 8.9 percent of no-load funds and 5.5 percent of load funds. For the fixed income category, almost $9.3 \%$ of direct-market bond funds advertise but only 4.0 percent of those funds with a load. The higher proportion of direct-market funds advertising is consistent with expectations. By definition, being broker-sold is at least a partial substitute for advertising since advisors actively promote these funds. However, the fact that funds in the direct market promote performance more often is interesting since Alexander, Jones, and Nigro (1998) find direct-market investors to be more financially savvy, thus seemingly less likely to chase performance.

\subsection{Empirical Methodology}

Our approach to measuring fund flows follows that of Nanda, Wang, and Zheng (2004), Jain and Wu (2000), Korkeamaki, Puttonen, and Smythe (2007) and others. Because fund size is affected both by performance and flows into and out of the fund, asset flows are adjusted for the performance of the fund during the calendar year. To compute asset flows net of returns, we adjust the assets of the fund at the beginning of the year for the return earned by the fund during the year as follows:

$$
\text { FLOW }_{\mathrm{i}, \mathrm{t}}=\left[\text { Assets }_{\mathrm{i}, \mathrm{t}}-\operatorname{Assets}_{\mathrm{i}, \mathrm{t}-1}\left(1+\mathrm{R}_{\mathrm{i}, \mathrm{t}}\right)\right] / \text { Assets }_{\mathrm{i}, \mathrm{t}-\mathrm{1}}
$$

where ASSETS refer to the total assets in fund class $i$ at the end of calendar year $t$ and $R_{i t}$ is the return of class $i$ during year $t$. Thus, the asset flow variable measures the asset growth in excess of the change in the value of the portfolio's asset base due to performance. Asset flows are normalized because funds vary significantly in size.

Our objective is to estimate the relationship between advertising in year $t-1$ and net asset flow in year $t$. Consider the following baseline empirical specification

$$
\mathrm{FLOW}_{\mathrm{i}, \mathrm{t}}=\mathrm{X}_{\mathrm{i}, \mathrm{\beta}} \mathrm{\beta}+\mathrm{Z}_{\mathrm{i}, \mathrm{t}-1} \gamma+\mathrm{AD} 9_{\mathrm{i}, \mathrm{t}-1} \delta+\varepsilon_{\mathrm{i}, \mathrm{t}}
$$

where FLOW is net asset flow defined by Equation (1), $X$ is a vector of fund characteristics in year $t$ (the year subsequent to the appearance of the ad), $Z$ is a vector of fund characteristics in year $t$-1 (the year coincident with the ad), and $\varepsilon$ is a random disturbance term. The specific control variables included in the vectors $X$ and $Z$ are discussed in more detail below.

The variable of interest in this specification is $A D 99$. In the baseline model this variable is a dichotomous indicator taking a value of one if the fund advertised at some point in year $t-1$ (1999). The parameter estimate $\delta$ provides an indication of how funds that advertised during 1999 perform in terms of net asset flow relative to characteristically similar funds that did not advertise. Care must be taken, however, when interpreting estimates of $\delta$. The decision to advertise is, presumably, a rational choice made by the fund company. Consequently, the ad variable is endogenous. 
Thus we cannot determine causality between advertising and fund flows, only whether or not a relation exists between the two.

We also hypothesize that ad content and fund characteristics of advertising funds play a role in the effectiveness of the ad in attracting fund flow. In order to test this potentiality, the baseline specification given by Equation (2) is augmented to include a variable identifying whether the ad promotes performance.

One of the factors separating this study from past research on advertising and asset flow is the utilization of an extensive set of control variables. We first discuss variables appearing in prior studies and conclude with new variables. All studies examining fund flows account for prior returns and find that investors chase performance. The construction of this variable varies somewhat across studies. A combination of raw return and risk-adjusted measures are commonly used (see Jain and Wu, 2000; Frye, 2001; Barber, et al., 2005; Zoran and Weisbenner, 2009). We use raw returns for the previous three years in our analysis. DelGuercio and Tkac (2002a) demonstrate that individual investors are more responsive to raw performance. Although not presented, our results are robust to the inclusion of a three-year risk-adjusted return measure.

In addition to past performance, we also include controls for lagged fund flow, the natural logarithm of lagged fund assets, and lagged operational expenses. Previous work finds persistence in fund flows from one period to the next (Korkeamaki et al, 2007, Atkinson, Baird, and Frye, 2003; DelGuercio and Tkac, 2002a). Studies also find an inverse relationship between lagged fund assets and fund flows (Sirri and Tufano, 1998; DelGuercio and Tkac, 2002b). More recently, lagged expense ratios have been included in empirical models to ascertain if investors are price conscious. Barber, et al. (2005) find that when marketing fees (12b-1 fees) are segregated from operating expenses (expense ratio minus the 12b-1 fee), 12b-1 fees are positively related to fund flows while higher operating expenses lead to lower flows. Similarly, Zoran and Weisbenner (2009) find that higher expense ratios impact the redemption decision of investors. The positive relationship between $12 \mathrm{~b}-1$ fees and flows is what lead Barber, et al. to conclude that marketing works. We also include the lagged operating expenses; however, we use an indicator variable equal to one if the fund has a $12 \mathrm{~b}-1$ fee. The use of the 12b-1 fee has changed dramatically since its introduction in 1980, when it was used primarily to recoup advertising costs from investors. With the wide scale introduction of MS funds in 1995, the $12 \mathrm{~b}-1$ fee now serves as an integral component of the commission structure for contingent deferred sales charge and level load funds. Since our data is from the year 2000, we control for the 12b-1 fee as it pertains to fund distribution more broadly (Note 9).

Fund family size has been shown to have a positive impact on fund flow (Sirri and Tufano, 1998; Christoffersen, 2001) (Note 10). We measure family size as the natural logarithm of fund family assets as of year-end 2000 . Barber, et al. (2005) introduce fund age, measured as the natural logarithm of fund age, to control for the rapid growth of newly introduced funds. DelGuercio and Tkac (2002b) examine the impact of Morningstar ratings changes on fund flows, given the perceived value of stars by investors, and find that new five star ratings and upgrades to five stars lead to higher flows. Knuutila, Puttonen, and Smythe (2007) find a similar result for Finnish mutual funds that are not distributed by banks. We focus on the influence of star ratings as of year-end 1999 and expect funds with more stars to have higher flows. Frye (2001) examines the difference in fund flows for bank-managed bond funds compared to non-bank operated bond funds and finds that the bank-managed funds appear less sensitive to past performance. We control for differences in flows between bank and non-bank funds with an indicator variable equal to one if a bank operates fund classes.

Our empirical model also includes new variables likely to impact flows. The first identifies whether the fund has been involved in a merger during 2000. There are 275 funds in our sample that receive merged assets, and we expect these funds to have higher flows. We also control for whether a fund has a minimum investment and if it does, what the minimum is. First, we include a dummy variable identifying those funds with no minimum investment. When the fund does have a minimum investment, we control for any impact on fund flow by including the natural logarithm of the minimum investment amount. If minimums are a significant determinant of asset flows, we expect both variables to exhibit an inverse relationship (Note 11).

The final new control captures the fund's organizational structure and is represented by the indicator MS, which is equal to one if the observation is a class of an MS portfolio and zero otherwise. Funds having an MS structure may be more appealing to broker-sold customers because the structure gives the investor more choice as to how one pays for the broker's service. As such, flows may be higher for all classes within an MS fund.

\subsection{Descriptive Statistics}

Tables 2, 3, and 4 present summary statistics for key variables used in the subsequent analysis, including variable means and standard deviations for the samples of domestic equity, all equity, and bond funds, respectively. The statistics in each 
table are presented for the full sample as well as for sub-samples of broker-sold and direct-market funds. In order to facilitate comparison, each sample and sub-sample is further partitioned by whether the funds advertised performance, advertised but did not include performance, or did not advertise.

Table 2 presents descriptive statistics for domestic equity funds. The first three columns pertain to the entire sample of domestic equity funds. On average, net flow was positive in both 2000 and 1999 (FLOWt and FLOWt-1, respectively) for each category with the exception of those funds advertising but not promoting performance. Funds advertising performance had, on average, higher flow than either of the other categories in both years. In 2000, the mean flow for funds that advertised performance is 0.328 as compared to -0.024 for funds not advertising performance and 0.224 funds that did not advertise. In 1999, performance-advertising funds had a mean flow of 0.567 as compared to only 0.029 and 0.292 for non-performance advertising funds and non-advertising funds, respectively. Other differences also emerge. Most suggestive is the fact that funds that specifically advertised performance demonstrated the highest prior year returns (PYRET) and Morningstar star ratings (MSTAR). Given that PYRET is accounted for in the calculation of MSTAR, one can argue that these funds are also superior relative to all others when takingrisk into account. This is consistent with such funds trying to parlay recent success into added flow. In contrast, funds that advertised but did not promote performance had, on average, lower prior year returns and Morningstar ratings than funds that chose not to advertise. In this case, such funds, not in a position to advertise performance, may consider advertising other fund characteristics potentially attractive to investors as part of a larger strategy to preserve the existing asset base. Finally, funds that advertised were less likely to be bank operated and have larger asset bases than non-advertising funds.

The next six columns of Table 2 allow us to compare broker-sold funds with those in the direct-market channel. Here we see a similar pattern of results, especially for the sub-sample of direct-market domestic equity funds (columns 7, 8, 9). The notable exceptions are to be found in the sub-sample of broker-sold domestic equity funds (columns $4,5,6)$ where funds that did not advertise tended to have the best prior year returns on average. This may, in part, explain why non-advertising funds also had the highest average flow in both 2000 and 1999 in the broker-sold domestic equity category, suggesting that advertising broker-sold funds may be unnecessary to attract flows when performance is strong.

Table 3 provides summary statistics for the larger sample of equity funds now inclusive of funds with special and international objectives. As would be expected, the variable means in this table generally mirror those of Table 2 with only a few exceptions. As in the domestic equity sample, funds that advertised performance had, on average, higher flow than either of the other categories in both years. The notable difference here is that mean flow in 2000 is now positive for funds advertising without promoting performance. Not surprisingly, funds that promoted performance again show the highest prior year returns and Morningstar star ratings, while funds advertising without promoting performance had lower mean prior year returns than funds choosing not to advertise. Lastly, advertising funds tended to have larger asset bases than non-advertising funds and were less likely to be operated by a bank.

When comparing broker-sold and direct-market funds in Table 3, we again see funds that advertised, whether promoting performance or not, had lower mean flow in both 1999 and 2000 than non-advertising funds in the broker-sold category. In the direct-market channel, however, funds advertising performance tended to have the highest flow in both years. In contrast to the domestic equity broker-sold sample, PYRET for performance advertising funds is higher in the all-equity sample and MSTAR is comparable or higher for all funds that advertise.

Table 4 provides summary statistics for the sample of fixed income funds. On average, bond funds have negative fund flow throughout calendar year 2000, but positive flow in 1999. This is not surprising given the less than stellar returns shown by fixed income funds in the previous year (PYRET). When comparing bond funds that advertised with non-advertising funds, we find that those that chose to advertise typically had lower net expenses, greater asset bases, and higher Morningstar ratings. Moreover, these same general patterns hold when the sample is further partitioned between broker-sold and direct-market funds. These findings suggest that characteristics other than performance, e.g. expenses and star ratings, are more critical to flow for bond funds, providing empirical motivation for examining these funds.

\section{Results}

\subsection{Baseline Empirical Specification}

\subsubsection{Pooled Sample Analysis}

Table 5 presents results from several alternative specifications of our baseline model in Equation (2) aimed at measuring the impact of advertising on fund flows. The results in this table most closely compare to those from Jain and Wu (2000). The dependent variable is net asset flow between calendar year 1999 and 2000 as defined by Equation (1). Each specification is estimated via ordinary least squares (OLS). All standard errors have been corrected for heteroskedasticity 
and correlation across classes within MS funds. In panel A, we present results for the largest 70 percent of retail domestic equity funds. Model (1) is the baseline specification. The variable of interest is the dichotomous indicator of whether the fund advertised in calendar year 1999 (AD99). The results from model (1) indicate that when all fund ads are considered equally there appears to be no relation between advertising and fund flows, as the coefficient estimate for AD99 is not significantly different than zero. This finding appears to contradict the findings of Jain and Wu, however, model (2) more accurately replicates their tests. In model (2), we only identify ads that specifically promote fund performance by using the indicator variable (APERF). Interestingly, the advertising coefficient estimate is now considerably larger than in model (1) and significant at the 10 percent level, suggesting that in fact it is ads promoting performance that lead to significantly higher flows, as found in Jain and Wu (2000) (Note 12). Finally in model (3), when we isolate whether the ad does promote performance (APERF) from all funds that advertise (AD99), neither form of advertising impacts asset flows at conventional levels.

Panel B displays results when expanding the sample to all equity funds from objective categories advertising in 1999. We aggregate the funds into the domestic equity (the omitted class), international equity, and special equity categories. As demonstrated in each of the three models, advertising has no significant impact on flow when pooling all equity funds, and this result is independent of how we classify ad variables. One possible explanation is that advertising has a negative impact on flows for special and international equity funds, thereby offsetting the positive effect for domestic equity funds. We re-estimate the model for only special and international equity funds and while the coefficient estimate is negative, it is not significant at conventional levels. We conclude that the effect of advertising appears limited to domestic equity funds.

Panel $\mathrm{C}$ of Table 5 provides the second of our new revelations regarding the impact of advertising on fund flows. Specifically, advertising leads to higher flows for fixed income funds. The parameter estimate for $A D 99$ is 0.026 and is significant at the 5 percent level. Given that only four fixed income fund ads promote performance, one conclusion that can be drawn is that ads for bond funds provide other information that reduces investor search cost and leads to higher fund flows. At a minimum, we can conclude that advertising does not have a consistent effect across all types of funds.

\subsubsection{Analysis by Investor Type}

Our attention turns to one of the primary questions addressed in the paper: Do retail investors from the two primary distribution channels respond to advertising similarly? The initial results are presented in Table 6 for each base sample. To conserve space, we do not present the model having only the indicator variable for ads promoting performance. The results across all three panels provide a telling story. In Panel A, we find that advertising is related to higher flows in domestic equity funds but only for investors in the broker-sold channel (1BS). When we control for whether the ad promotes performance (2BS), we see that there is no incremental effect from specifically promoting performance, and the coefficient estimate for $A D 99$ remains large and highly significant. In contrast, we see that no-load investors from the direct-market channel (models denoted by DM) do not appear to respond to advertising, a finding consistent with Capon, et al (1996).

As was the case for the pooled equity sample in Table 5, we find advertising has little effect on fund flows when looking at the broader sample of equity funds in Panel B of Table 6. The exception is that advertising, independent of content, is related to lower fund flows when the ad is targeted at the direct-market channel, a result driven by the inclusion of the special and international equity funds, representing a new finding in the literature.

When examining fixed income funds with the baseline specification in Panel $\mathrm{C}$, we find once again that advertising to investors in the broker-sold channel appears to work, similar to the domestic equity sample. Ads for funds directed at these investors are related to significantly higher flows, but ads for fixed income funds targeted at no-load investors have no marginal effect on subsequent flows.

Together, the results obtained using a simplified empirical specification similar to Jain and Wu (2000) suggest that advertising works best when targeted to investors in the broker-sold channel. This finding is consistent with the survey results of Capon, et al. (1996) who find that direct-market investors rely less on advertising than those from the broker-sold channel.

The results from Table 6 also raise an interesting question. While Capon, et al. and Alexander, et al. (1998) find that no-load investors rely less on advertising and are more financially knowledgeable, such findings ignore the role of the financial advisor in the fund purchase decision. Assuming that advisors are involved with decisions in the broker-sold channel, our results suggest that either the investor identifies a fund via an ad, goes to the advisor, and asks that the fund be purchased, or that the advisor is responding to the ad in Money or some other information regarding the distribution of the same fund. Neither explanation seems consistent with the advisor fulfilling their fiduciary duty to the client. 
Combined with the results of O'Neal(2004), which finds load investors chase performance more aggressively, evidence is mounting calling into question the effectiveness of financial advisors.

\subsection{Expanded Empirical Specification}

\subsubsection{Domestic Equity Funds}

Another primary contribution of this paper is to expand the empirical specification of Tables 5 and 6 . Work subsequent to Jain and $\mathrm{Wu}$ (2000) (e.g. Christoffersen, 2001; Frye, 2001; DelGuercio and Tkac, 2002 a,b; Barber, et al., 2005), as well as the discussion above, indicates that a broader range of factors influence fund asset flows. As such, our initial results may be subject to model misspecification. A complete list of the variables used in the expanded specification and their definitions is found in Table A1 of the Appendix and are discussed above in the data section. To conserve space, we only present results for the direct-market and broker-sold channels for each sample of funds.

The results for the expanded specification are presented in Table 7, where each column represents a fund sub-sample categorized by investor type. The advertising variables are captured by AD99 and APERF as before. Columns 1 and 2 display the results for the sub-sample of domestic equity funds separately for investors in the broker-sold (BS) and direct-market (DM) channels. Focusing first on the advertising variables, we see that controlling for a broader range of factors has a significant impact on how advertising influences fund flows in the direct-market channel. In Panel A of Table 6 (model 2DM), advertising has no influence on fund flows. When controlling for other characteristics in Table 7, however, we find that advertised funds (AD99), independent of content, experience significantly lower flows in the direct-market channel. Additionally, the coefficient estimate for APERF indicates that when funds also advertise performance to no-load investors, there is a marginal increase in flows. So while Capon, et al (1996) find no-load investors say they use advertising less, they appear to respond strongly to ads promoting performance, a finding questioning the idea that these investors are more financially savvy but consistent with the findings in Pontari et al (2009). In contrast, the results for the ad variables in column one for investors in the broker-sold channel indicate that the results from Table 6 are not contingent upon controlling for other fund characteristics. In fact the marginal effect, as measured by the coefficient estimates, is almost identical when comparing the results in Tables 6 and 7 for broker-sold funds. In total, these results suggest that while advertising works for domestic equity funds, as postulated by Jain and $\mathrm{Wu}$ (2000), it works differently depending on the target distribution channel and the content of the ad in the case of the direct-market channel.

In addition to the results for the ad variables, we briefly discuss the impact of the control variables. While generally consistent with previous research, the results vary by distribution channel. We begin by addressing variables new to the literature. MERGE identifies asset pools that have been combined during the year 2000 and as expected, the coefficient estimate is positive and significant, indicating those funds have substantially higher flows. Additionally, the results indicate that not having a minimum investment amount (NOMIN) is not statistically related to asset flows in the broker-sold market, but for direct-marketed funds the coefficient estimate is negative and significant, as expected. Also, retail funds with higher minimum investments $(L N M I N)$ have lower flows in the direct-market channel. Observations identified as being part of a MS structure do not have any advantage (disadvantage) that results specifically from the structure, as the $M S$ variable is not significant for either investor type for domestic equity funds.

The results for other control variables from previous literature are generally consistent with prior research, with several exceptions noted below. There is an inverse relationship between fund asset size and flows and a positive relationship between fund complex size and asset flow. As expected, investors chase past performance, but in the expanded model only 1999 returns are significant, unlike results from Table 6. Investors in the broker-sold and direct-market channels pour money into funds with high prior year performance. Additionally, investors in the broker-sold channel do value Morningstar ratings, as funds with higher ratings from 1999 have higher flows as expected and consistent with DelGuercio and Tkac (2002 b).

While lagged fund flows (FLOWt-1) lead to higher flows in the broker-sold channel, consistent with prior research, lagged flows are not a significant determinant of flows in the direct channel. One possible explanation is that financial advisors often use preferred fund lists. As such, they may consistently use the same funds over time, independent of other factors such as performance or cost. In contrast, direct-market investors may not have the same sense of loyalty to any one fund or fund complex that would lead to continued flows over time.

The inclusion of fund expenses is relatively new to the literature. Barber, et al. (2005) finds that when they control for 12b-1 fees separately from operational expenses, higher operational expenses lead to lower flows. We control for 12b-1 fees with the indicator MKTFEE instead of the 12b-1 fee level to account for the broader distribution role the 12b-1 fee now serves. NETEXP $P_{t-1}$ is the fund's lagged operational expense ratio. The coefficient estimate for MKTFEE is not 
significantly different from zero. This suggests that investors are not concerned with the presence of a $12 \mathrm{~b}-1$ fee even though prior research (see Malhotra and McLeod, 1997) demonstrates the fee is a deadweight cost for investors. In contrast to Barber, et al. (2005), we do not find that higher operational expenses lead to lower flows, regardless of distribution channel. Several explanations for the difference are possible. First, Barber, et al. (2005) use a time series of approximately 20 years in their sample and base their conclusion on a times series average. Second, they employ a different empirical model that does not control for the same effects as we do here. Finally, we find that bank-sold domestic equity funds have significantly lower fund flows independent of distribution channel.

\subsubsection{All Equity Funds}

The results for the expanded empirical model using the sample of all equity funds are presented in columns three and four of Table 7. With regard to the variables of interest, $A D 99$ and $A P E R F$, we find the results to be similar to those in Table 6. Advertised funds that do not promote performance suffer significantly lower flows for funds in the direct-market channel. The coefficient estimate is larger in absolute magnitude and its statistical power improves dramatically. In addition, we find funds in the all-equity sample advertising performance to the direct-market channel experience marginally higher flows. So, it once again appears that while in general, ads for no-load funds are not related to increased fund flows ads touting performance appear more successful, even though prior research (e.g. Jain and Wu, 2000, and Carhart, 1997) demonstrates that superior performance does not persist.

The impact of the control variables on fund flows in the all-equity sample is generally consistent with those in columns one and two. Three exceptions are worth noting. First, prior year returns (PYRET99) are not as important in explaining subsequent flows when including the special and international equity categories in the sample, which is somewhat surprising since it is these fund types, especially special fund categories such as biotechnology, generating the largest returns in 1999. However, it is the very large returns that investors may not feel can be maintained (Note 13). Finally, the coefficient estimate for the $M S$ variable is negative and statistically significant for the direct-market channel of all equity funds. A likely explanation for this finding is that most $M S$ funds are sold through financial advisors and only have commission-based classes, making any no-load classes difficult to market.

\subsubsection{Fixed Income Funds}

Next, we examine the impact of advertising on bond fund flows using the expanded empirical model. The results are presented in columns five and six of Table 7. Focusing first on the ad variable $A D 99$ (APERF is excluded due to the absence of bond advertisements promoting performance) we find that model misspecification plays an important role in the results when compared to the findings in Table 6 . For the broker-sold sample in column five, we see that advertising no longer has a significant impact on fund flows, once we control for a broader range of fund characteristics. Advertising, however, is related to lower flows for fixed income funds when ads are targeted to no-load investors. When combined with the results for equity fund samples sold through the direct-market channel, one conclusion to be drawn is that direct-market investors see advertising without performance information as a negative signal. Ironically, Jones, et al. (2003) find that domestic equity funds advertising performance have higher expenses and historical risk as measured by standard deviation, yet these funds have higher flows resulting from their advertising. In contrast, Jones, et al. find bond funds that advertise have lower expenses and standard deviations, yet the results here indicate these funds have lower flows, a counterintuitive result ceteris paribus. Both results argue against investors in the direct-market channel being "savvier" when it comes to using information to make fund purchase decisions as suggested by Capon, et al (1996).

The results for the control variables are worthy of discussion, since many contrast with those from either equity sample. First, lagged flow (FLOWt-1) has no impact on current flows for fixed income funds, independent of distribution channel, contrary to the findings of previous studies and our own results for broker-sold equity funds. Additionally, bond funds with higher operational expenses (NETEXPt-1) have lower fund flows in the direct-market channel, in contrast to the results for the equity fund samples in columns two and four. We believe these results are support for the hypothesis that investors treat the equity and bond asset classes as fundamentally different products and therefore rely on different informational characteristics when making purchase decisions. Fund expenses have a much larger impact on bond fund returns, when compared to equity funds. Consequently, investors (at least those in the direct-market channel) appear to concentrate more attention on this characteristic when deciding on a bond fund purchase.

Unlike the results for the direct-marketed equity samples in columns two and four, the size of the minimum investment $(L N M I N)$ is not a significant determinant of fixed income fund flows (Note 14). Moreover, neither type of investor shied away from bank-managed bond funds. While fund size and fund family/complex size have similar directional effects in the fixed income sample relative to the equity samples, the magnitudes are substantially smaller for bond funds. Equity fund asset size has an effect that is approximately three times that for bond funds, while the family size effect is approximately four times larger for equity funds. Similarly, the effect of higher star ratings is not as large when 
compared to equity funds. The latter result may reflect the more homogenous nature of bond funds when compared to equity funds. Investors realize that the divergence in returns across bond funds is smaller when compared to equity funds, so star ratings play a smaller role in this product market.

Finally, the control variable having the most significant difference between samples is PYRET99. While the effect of prior year returns is still positive and significant in the broker-sold channel, fixed income investors in the direct-market channel appear to have ignored prior returns, as the coefficient estimate for PYRET99 is not significant in column 6.

\section{Conclusions}

Previous research suggests that advertising fund performance leads to higher flows in subsequent periods, even after controlling for fund performance. We find that advertising does work, though differently for equity and bond funds and by distribution channel. Specifically, advertising appears to be most effective in the broker-sold channel, independent of whether ads promote performance or not. Combined with the results of O'Neal (2004) and Shrider (2009), which finds that investors in the broker-sold channel more aggressively chase performance, questions are mounting as to the effectiveness of advisors and/or the willingness of these investors to accept the advice provided.

Advertising is also effective for funds marketed directly to consumers, though only when advertising performance, contrary to the survey results of Capon, et al. (1996). While no-load investors perceive themselves as less responsive to advertising, our data suggest their actual behavior is quite different. These results are somewhat sensitive to both sample and empirical specification.

Finally, the response by investors to bond fund advertising differs from equity funds. Bond fund asset flows are shown to be higher for funds that advertise in the broker-sold channel when our baseline specification is employed. When we expand the empirical specification, however, advertising has no effect on bond fund flows in the broker-sold market and is related to a lower flow to funds in the direct-market channel. The evidence for bond funds is of interest since so few bond funds advertise performance. Hence, it would appear that investors respond differently to ad content depending on product type.

\section{References}

Alexander, G. J., Jones, J. D., \& Nigro, P. J. (1998). Mutual fund shareholders: characteristics, investor knowledge, and sources of information. Financial Services Review, 7, 301-316. doi:10.1016/S1057-0810(99)00023-2, http://dx.doi.org/10.1016/S1057-0810(99)00023-2

Atkinson, S.M., Baird, S. B., \& Frye, M. B. (2003). Do female mutual fund managers manage differently? Journal of Financial Research 26, 1-18. doi:10.1111/1475-6803.00041, http://dx.doi.org/10.1111/1475-6803.00041

Barber, B.M., Odean, T. \& Zheng, L. (2005). Out of sight, out of mind: The effects of expenses on mutual fund flows. Journal of Business 78, 2095-2119. doi:10.1086/497042, http://dx.doi.org/10.1086/497042

Belch, G.E. \& Belch, M. A. (2004). Advertising and Promotion: An Integrated Marketing Communications Perspective. Irwin-McGraw Hill.

Bogle, J. C. (1999). Common sense on mutual funds. New York: John Wiley \& Sons.

Capon, N., Fitzsimmons, G. J. \& Prince, R. A. (1996). An individual level analysis of the mutual fund investment decision. Journal of Financial Services Research 10, 59-82. doi:10.1007/BF00120146, http://dx.doi.org/10.1007/BF00120146

Carhart, M. M. (1997). On persistence in mutual fund performance. Journal of Finance 52, 56-82. doi:10.2307/2329556, http://dx.doi.org/10.2307/2329556

Chevalier, J. \& Ellison, G. (1997). Risk taking by mutual funds as a response to incentives. Journal of Political Economy 105, 1167-1200. doi:10.1086/516389, http://dx.doi.org/10.1086/516389

Christoffersen, S. E. K. (2001). Why do money managers fund managers voluntarily waive their fees? Journal of Finance 56, 1117-1140. doi:10.1111/0022-1082.00358, http://dx.doi.org/10.1111/0022-1082.00358

Del Guercio, D. \& Tkac, P. A. (2002a). The determinants of the flow of funds of managed portfolios: Mutual funds vs. pension funds, Journal of Financial and Quantitative Analysis 37, 523-557. doi:10.2307/3595011, http://dx.doi.org/10.2307/3595011

Del Guercio, D. \& Tkac, P. A. (2002b). Star power: The effect of Morningstar ratings on mutual fund flows. Working paper, University of Oregon.

Dermine, J. \& Roller, L. H. (1992). Economies of scale and scope in French mutual funds. Journal of Financial Intermediation 2, 83-93. doi:10.1016/1042-9573(92)90021-5, http://dx.doi.org/10.1016/1042-9573(92)90021-5 
Elton, E. J., Gruber, M. J., \& Blake, C. R. (1996). The persistence of risk-adjusted mutual fund performance. Journal of Business 69, 133-157. doi:10.1086/209685, http://dx.doi.org/10.1086/209685

Elton, E. J., Gruber, M. J., \& Blake, C. R. (2003). Incentive fees and mutual funds. Journal of Finance 58, 779-804. doi:10.1111/1540-6261.00545, http://dx.doi.org/10.1111/1540-6261.00545

Frye, M. B. (2001). The performance of bank-managed mutual funds. Journal of Financial Research 24, 419-442.

Jain, P. C. \& Wu, J. S. (2000). Truth in mutual fund advertising: evidence of future performance and fund flows. Journal of Finance 55, 937-958. doi:10.1111/0022-1082.00232, http://dx.doi.org/10.1111/0022-1082.00232

Jones, M. A., Lesseig, V. P., \& Smythe, T. I. (2003). Mutual fund advertising: Reading between the lines. Working paper, Furman University.

Jones, M. A., Lesseig, V. P., \& Smythe, T. I. (2004). Financial advisors and mutual fund selection. Working paper, Furman University.

Jones, M. A. \& Smythe, T. I. (2003). An examination of the information content of mutual fund print advertising.

Journal of Consumer Affairs 37, 48-67. doi:10.1111/j.1745-6606.2003.tb00438.x,

http://dx.doi.org/10.1111/j.1745-6606.2003.tb00438.x

Knuutila, M., Puttonen, V. \& Smythe, T. (2007). The effect of distribution channels on mutual funds flows. Journal of

Financial Services Marketing 12, 88-96. doi:10.1057/palgrave.fsm.4760058,

http://dx.doi.org/10.1057/palgrave.fsm.4760058

Korkeamaki, T., Puttonen, V., \& Smythe, T. (2007). Advertising and mutual funds asset flows. International Journal of

Bank Marketing 25, 434-451. doi:10.1108/02652320710832603, http://dx.doi.org/10.1108/02652320710832603

Kliger, D., Levy, O. \& Sonsino, D. (2003). On absolute and relative performance and the demand for mutual funds experimental evidence. Journal of Economic Behavior and Organization 52, 341-363.

doi:10.1016/S0167-2681(03)00032-5, http://dx.doi.org/10.1016/S0167-2681(03)00032-5

Latzko, D.A. (1999). Economies of scale in mutual fund administration. Journal of Financial Research 22, 331-339.

Lesseig, V. P., Long, D. M. \& Smythe, T. I. (2002). Gains to mutual fund sponsors offering multiple share class funds. Journal of Financial Research 25, 81-98. doi:10.1111/1475-6803.00005, http://dx.doi.org/10.1111/1475-6803.00005

Livingston, M. \& O'Neal, E. S. (1998). The cost of mutual fund distribution fees. Journal of Financial Research. 21, 205-218.

Malhotra, D. K. \& McLeod, R. W. (1997). An empirical analysis of mutual fund expenses. Journal of Financial Research 20, 175-190.

Malkiel, B. G. (1995). Returns from investing in equity mutual funds 1971 to 1991. Journal of Finance 50, 549-572. doi:10.2307/2329419, http://dx.doi.org/10.2307/2329419

Nanda, V., Wang, Z. J., \& Zheng, L. (2004). Family values and the star phenomenon: Strategies of mutual fund families. Review of Financial Studies 17, 667-698.

O’Neal, E. S. (2004). Purchase and Redemption Patterns of US Equity Mutual Funds. Financial Management 33, 63-90.

Pontari, B., Stanaland, A. \& Smythe, T. (2009). Regulating information disclosure in mutual fund advertising in the United States: will consumers utilize cost information? Journal of Consumer Policy 32, 333-351. doi:10.1007/s10603-009-9107-8, http://dx.doi.org/10.1007/s10603-009-9107-8

Rogers, W. H. (1993). Regression standard errors in clustered samples. Stata Technical Bulletin 13, 19-23.

Shrider, D. G. (2009). Running from a bear: How poor stock market performance affects the determinants of mutual fund flows. Journal of Business Finance \& Accounting 36, 987-1006. doi:10.1111/j.1468-5957.2009.02149.x, http://dx.doi.org/10.1111/j.1468-5957.2009.02149.x

Sirri, E. \& Tufano, P. (1998). Costly search and mutual fund flows. Journal of Finance 53, 1589-1622. doi:10.1111/0022-1082.00066, http://dx.doi.org/10.1111/0022-1082.00066

Tufano, P. \& Sevick, M. (1997). Board structure and fee-setting in the U.S. mutual fund industry. Journal of Financial Economics 46, 321-355. doi:10.1016/S0304-405X(97)00033-0, http://dx.doi.org/10.1016/S0304-405X(97)00033-0

Zoran, I. \& Weisbenner, S. (2009). Individual investor mutual fund flows. Journal of Financial Economics 92, 223-237. doi:10.1016/j.jfineco.2008.05.003, http://dx.doi.org/10.1016/j.jfineco.2008.05.003 


\section{Notes}

Note 1. In their sample of advertisements from Money magazine in 1999, Jones and Smythe (2003) finds 47.6\% of ads for specific funds do not mention performance.

Note 2. Shrider (2009) includes all fund types in his analysis. However, his focus is on fund level transaction patterns. In his sample, only about $7 \%$ of funds are in the fixed income category.

Note 3. Jain and $\mathrm{Wu}(2000)$ and Jones, et al. (2003) both demonstrate that advertising funds have strong recent raw and risk-adjusted performance in the period leading up to the advertisement.

Note 4. The question of whether increased flow is of value to investors is open for debate. The primary argument is that a larger asset base leads to economies of scale. However, Dermine and Roller (1992) and Latzko (1999) show that large funds have constant returns to scale at best and diseconomies of scale at worst. The value to managers for increased asset flows is more obvious since revenues are calculated as a percentage of assets.

Note 5. This data comes from the Investment Company Institute's Factbook 2010, but these values exclude money market funds.

Note 6. See Table 3a of Capon, et al. (1996), specifically the columns "Commission-based Advisees" and "Knowledge-Based Investors."

Note 7. Jain and $\mathrm{Wu}(2000)$ reach the same conclusion concerning ad overlap.

Note 8 . Three of these factors are flow measures at different lags.

Note 9. Our results are qualitatively similar if we use the level of the $12 \mathrm{~b}-1$ fee or remove it from the model, although statistical power on advertising variables weakens slightly when the $12 \mathrm{~b}-1$ fee is excluded from the model.

Note 10. Korkeamaki et al, (2007) find no relationship for family size and fund flows for the Finnish fund market.

Note 11. Fund minimums in Morningstar's software represent the minimum for investors not investing in IRA's, which have annual limits that are sometimes below investment minimums for the year 2000, or using monthly bank drafts.

Note 12. Funds that advertise but do not promote performance are in the omitted group. We present the results with them included because these funds would fall in our control group. However, our results are robust to the exclusion of these funds from the sample.

Note 13. While evidence shows that funds do not persist in performance, investors may agree with this evidence when returns are grossly outsized for a given year.

Note 14. NOMIN is excluded from the estimation in the broker-sold channel for bond funds since all observations have a stated minimum investment amount. 
Table 1. Advertising by fund type

\begin{tabular}{|c|c|c|c|}
\hline Panel A: domestic equity funds & Broker Sold & Direct Market & Total \\
\hline Advertised performance & $\begin{array}{l}1.9 \% \\
(14)\end{array}$ & $\begin{array}{c}4.3 \% \\
(33)\end{array}$ & $\begin{array}{l}3.1 \% \\
(47)\end{array}$ \\
\hline Advertised, but not performance & $\begin{array}{l}3.0 \% \\
(22)\end{array}$ & $\begin{array}{l}4.7 \% \\
(36)\end{array}$ & $\begin{array}{l}3.9 \% \\
(58)\end{array}$ \\
\hline Advertised & $\begin{array}{c}4.9 \% \\
(36)\end{array}$ & $\begin{array}{l}9.1 \% \\
(69)\end{array}$ & $\begin{array}{l}7.0 \% \\
(105)\end{array}$ \\
\hline Did not advertise & $\begin{array}{l}95.1 \% \\
(703)\end{array}$ & $\begin{array}{c}90.9 \% \\
(692)\end{array}$ & $\begin{array}{l}93.0 \% \\
(1395)\end{array}$ \\
\hline Total & $\begin{array}{l}100 \% \\
(739)\end{array}$ & $\begin{array}{l}100 \% \\
(761)\end{array}$ & $\begin{array}{l}100 \% \\
(1500)\end{array}$ \\
\hline Panel B: all equity funds & Broker Sold & Direct Market & Total \\
\hline Advertised Performance & $\begin{array}{l}1.7 \% \\
(19)\end{array}$ & $\begin{array}{c}4.5 \% \\
(48)\end{array}$ & $\begin{array}{l}3.1 \% \\
(67)\end{array}$ \\
\hline Advertised, But Not Performance & $\begin{array}{l}3.8 \% \\
(43)\end{array}$ & $\begin{array}{l}4.4 \% \\
(46)\end{array}$ & $\begin{array}{l}4.1 \% \\
(89)\end{array}$ \\
\hline Advertised & $\begin{array}{l}5.5 \% \\
(62)\end{array}$ & $\begin{array}{l}8.9 \% \\
(94)\end{array}$ & $\begin{array}{l}7.1 \% \\
(156)\end{array}$ \\
\hline Did Not Advertise & $\begin{array}{l}94.5 \% \\
(1074) \\
\end{array}$ & $\begin{array}{l}91.1 \% \\
(961)\end{array}$ & $\begin{array}{l}92.9 \% \\
(2035) \\
\end{array}$ \\
\hline Total & $\begin{array}{c}100 \% \\
(1136)\end{array}$ & $\begin{array}{c}100 \% \\
(1055)\end{array}$ & $\begin{array}{l}100 \% \\
(2191)\end{array}$ \\
\hline Panel C: fixed income funds & Broker Sold & Direct Market & Total \\
\hline Advertised Performance & $\begin{array}{c}0.0 \% \\
(0)\end{array}$ & $\begin{array}{c}0.5 \% \\
(4)\end{array}$ & $\begin{array}{c}0.2 \% \\
(4)\end{array}$ \\
\hline Advertised, But Not Performance & $\begin{array}{l}4.0 \% \\
(46)\end{array}$ & $\begin{array}{l}8.8 \% \\
(74)\end{array}$ & $\begin{array}{l}6.1 \% \\
(120)\end{array}$ \\
\hline Advertised & $\begin{array}{l}4.0 \% \\
(46)\end{array}$ & $\begin{array}{c}9.3 \% \\
(78)\end{array}$ & $\begin{array}{l}6.3 \% \\
(124)\end{array}$ \\
\hline Did Not Advertise & $\begin{array}{l}96.0 \% \\
(1093)\end{array}$ & $\begin{array}{c}90.7 \% \\
(762)\end{array}$ & $\begin{array}{l}93.7 \% \\
(1855)\end{array}$ \\
\hline Total & $\begin{array}{l}100 \% \\
(1139)\end{array}$ & $\begin{array}{l}100 \% \\
(840)\end{array}$ & $\begin{array}{l}100 \% \\
(1979)\end{array}$ \\
\hline
\end{tabular}

Sample of funds collected from Morningstar's Principia software. Advertising identified in Money magazine during calendar year 1999.

Table 2. Descriptive statistics: domestic equity funds

\begin{tabular}{|c|c|c|c|}
\hline & \multicolumn{3}{|c|}{ All domestic equity funds } \\
\hline Variable & Advertised performance & Advertised, but not performance & Did not advertise \\
\hline FLOW $_{\mathrm{t}}$ & 0.328 & -0.024 & 0.238 \\
& $(0.561)$ & $(0.358)$ & $(0.763)$ \\
\hline FLOW $_{\mathrm{t}-1}$ & 0.567 & 0.029 & 0.292 \\
& $(1.735)$ & $(0.402)$ & $(2.529)$ \\
\hline LNASSETS & 7.589 & 6.800 & 5.743 \\
& $(1.319)$ & $(1.519)$ & $(1.415)$ \\
\hline MERGE & 0.0 & 0.034 & 0.034 \\
& $(0.0)$ & $(0.184)$ & $(0.182)$ \\
\hline NETEXP & 0.942 & 0.830 & 0.955 \\
& $(0.245)$ & $(0.310)$ & $(0.322)$ \\
\hline LNMIN & 7.325 & 7.161 & $(2.877)$ \\
& $(1.725)$ & $(2.596)$ & 0.039 \\
\hline NOMIN & 0.021 & 0.086 & $(0.193)$ \\
& $(0.146)$ & $(0.283)$ & \\
\hline
\end{tabular}




\begin{tabular}{|c|c|c|c|}
\hline PYRET & $\begin{array}{c}0.409 \\
(0.328) \\
\end{array}$ & $\begin{array}{c}0.181 \\
(0.160)\end{array}$ & $\begin{array}{c}0.289 \\
(0.286)\end{array}$ \\
\hline MSTAR $_{\mathrm{t}-1}$ & $\begin{array}{c}4.255 \\
(0.765)\end{array}$ & $\begin{array}{c}3.241 \\
(1.159)\end{array}$ & $\begin{array}{c}3.323 \\
(1.082)\end{array}$ \\
\hline BANK & $\begin{array}{c}0.043 \\
(0.204)\end{array}$ & $\begin{array}{c}0.052 \\
(0.223)\end{array}$ & $\begin{array}{c}0.156 \\
(0.363)\end{array}$ \\
\hline $\mathrm{N}$ & 47 & 58 & 1395 \\
\hline & \multicolumn{3}{|c|}{ Broker-sold funds } \\
\hline Variable & Advertised performance & Advertised, but not performance & Did not advertise \\
\hline $\mathrm{FLOW}_{\mathrm{t}}$ & $\begin{array}{c}0.141 \\
(0.339)\end{array}$ & $\begin{array}{c}0.041 \\
(0.452)\end{array}$ & $\begin{array}{c}0.268 \\
(0.742)\end{array}$ \\
\hline $\mathrm{FLOW}_{\mathrm{t}-1}$ & $\begin{array}{c}0.076 \\
(0.391)\end{array}$ & $\begin{array}{c}0.005 \\
(0.326)\end{array}$ & $\begin{array}{c}0.293 \\
(1.443)\end{array}$ \\
\hline LNASSETS & $\begin{array}{c}7.616 \\
(0.996) \\
\end{array}$ & $\begin{array}{c}6.796 \\
(1.295)\end{array}$ & $\begin{array}{c}5.725 \\
(1.453)\end{array}$ \\
\hline MERGE & $\begin{array}{c}0.0 \\
(0.0)\end{array}$ & $\begin{array}{c}0.091 \\
(0.294)\end{array}$ & $\begin{array}{c}0.034 \\
(0.182)\end{array}$ \\
\hline $\operatorname{NETEXP}_{\mathrm{t}-1}$ & $\begin{array}{c}0.802 \\
(0.280)\end{array}$ & $\begin{array}{c}0.883 \\
(0.281)\end{array}$ & $\begin{array}{c}0.982 \\
(0.302)\end{array}$ \\
\hline LNMIN & $\begin{array}{c}6.047 \\
(1.784)\end{array}$ & $\begin{array}{c}7.000 \\
(0.174)\end{array}$ & $\begin{array}{c}6.742 \\
(0.758)\end{array}$ \\
\hline NOMIN & $\begin{array}{c}0.071 \\
(0.267)\end{array}$ & $\begin{array}{c}0.0 \\
(0.0)\end{array}$ & $\begin{array}{c}0.0 \\
(0.0)\end{array}$ \\
\hline PYRET & $\begin{array}{c}0.246 \\
(0.105)\end{array}$ & $\begin{array}{c}0.167 \\
(0.162)\end{array}$ & $\begin{array}{c}0.307 \\
(0.284)\end{array}$ \\
\hline MSTAR $_{\mathrm{t}-1}$ & $\begin{array}{l}3.714 \\
(0.611)\end{array}$ & $\begin{array}{c}2.864 \\
(1.283)\end{array}$ & $\begin{array}{c}3.297 \\
(1.069)\end{array}$ \\
\hline BANK & $\begin{array}{c}0.0 \\
(0.0) \\
\end{array}$ & $\begin{array}{c}0.0 \\
(0.0) \\
\end{array}$ & $\begin{array}{c}0.114 \\
(0.318)\end{array}$ \\
\hline \multirow[t]{2}{*}{$\mathrm{N}$} & 14 & 22 & 703 \\
\hline & \multicolumn{3}{|c|}{ Direct-market funds } \\
\hline Variable & Advertised performance & Advertised, but not performance & Did not advertise \\
\hline $\mathrm{FLOW}_{\mathrm{t}}$ & $\begin{array}{c}0.407 \\
(0.619)\end{array}$ & $\begin{array}{l}-0.064 \\
(0.286)\end{array}$ & $\begin{array}{c}0.208 \\
(0.783)\end{array}$ \\
\hline $\mathrm{FLOW}_{\mathrm{t}-1}$ & $\begin{array}{c}0.775 \\
(2.029)\end{array}$ & $\begin{array}{c}0.043 \\
(0.445)\end{array}$ & $\begin{array}{c}0.291 \\
(3.284)\end{array}$ \\
\hline LNASSETS & $\begin{array}{c}7.577 \\
(1.448)\end{array}$ & $\begin{array}{c}6.802 \\
(1.659)\end{array}$ & $\begin{array}{c}5.761 \\
(1.375)\end{array}$ \\
\hline MERGE & $\begin{array}{c}0.0 \\
(0.0)\end{array}$ & $\begin{array}{c}0.0 \\
(0.0)\end{array}$ & $\begin{array}{c}0.035 \\
(0.183)\end{array}$ \\
\hline NETEXP $_{\mathrm{t}-1}$ & $\begin{array}{c}1.001 \\
(0.205)\end{array}$ & $\begin{array}{c}0.797 \\
(0.326)\end{array}$ & $\begin{array}{c}0.928 \\
(0.339)\end{array}$ \\
\hline LNMIN & $\begin{array}{c}7.867 \\
(1.402)\end{array}$ & $\begin{array}{c}7.259 \\
(3.306)\end{array}$ & $\begin{array}{c}8.666 \\
(3.775)\end{array}$ \\
\hline NOMIN & $\begin{array}{c}0.0 \\
(0.0)\end{array}$ & $\begin{array}{c}0.139 \\
(0.351)\end{array}$ & $\begin{array}{c}0.078 \\
(0.268)\end{array}$ \\
\hline PYRET & $\begin{array}{c}0.478 \\
(0.365)\end{array}$ & $\begin{array}{c}0.189 \\
(0.161)\end{array}$ & $\begin{array}{c}0.271 \\
(0.287)\end{array}$ \\
\hline MSTAR $_{\mathrm{t}-1}$ & $\begin{array}{c}4.485 \\
(0.712)\end{array}$ & $\begin{array}{c}3.472 \\
(1.028)\end{array}$ & $\begin{array}{c}3.350 \\
(1.096)\end{array}$ \\
\hline BANK & $\begin{array}{c}0.061 \\
(0.242)\end{array}$ & $\begin{array}{c}0.083 \\
(0.280)\end{array}$ & $\begin{array}{c}0.199 \\
(0.400)\end{array}$ \\
\hline $\mathrm{N}$ & 33 & 36 & 692 \\
\hline
\end{tabular}

Standard deviations in parentheses. Variable descriptions can be found in Appendix Table A1. 
Table 3. Descriptive statistics: all equity funds

\begin{tabular}{|c|c|c|c|}
\hline & \multicolumn{3}{|c|}{ All equity funds } \\
\hline Variable & Advertised performance & Advertised, but not performance & Did not advertise \\
\hline $\mathrm{FLOW}_{\mathrm{t}}$ & $\begin{array}{c}0.331 \\
(0.534) \\
\end{array}$ & $\begin{array}{c}0.029 \\
(0.445) \\
\end{array}$ & $\begin{array}{c}0.241 \\
(0.719) \\
\end{array}$ \\
\hline $\mathrm{FLOW}_{\mathrm{t}-1}$ & $\begin{array}{c}3.061 \\
(17.487) \\
\end{array}$ & $\begin{array}{c}0.073 \\
(0.505)\end{array}$ & $\begin{array}{c}0.285 \\
(2.328)\end{array}$ \\
\hline LNASSETS & $\begin{array}{c}7.410 \\
(1.396)\end{array}$ & $\begin{array}{c}6.489 \\
(1.608)\end{array}$ & $\begin{array}{c}5.562 \\
(1.425)\end{array}$ \\
\hline MERGE & $\begin{array}{c}0.015 \\
(0.122) \\
\end{array}$ & $\begin{array}{c}0.022 \\
(0.149) \\
\end{array}$ & $\begin{array}{c}0.041 \\
(0.198) \\
\end{array}$ \\
\hline NETEXP $_{\mathrm{t}-1}$ & $\begin{array}{c}1.008 \\
(0.283) \\
\end{array}$ & $\begin{array}{c}0.950 \\
(0.357) \\
\end{array}$ & $\begin{array}{c}1.030 \\
(0.357) \\
\end{array}$ \\
\hline LNMIN & $\begin{array}{c}7.419 \\
(1.461)\end{array}$ & $\begin{array}{c}6.796 \\
(2.582)\end{array}$ & $\begin{array}{c}7.704 \\
(2.826)\end{array}$ \\
\hline NOMIN & $\begin{array}{c}0.015 \\
(0.122) \\
\end{array}$ & $\begin{array}{c}0.101 \\
(0.303) \\
\end{array}$ & $\begin{array}{c}0.036 \\
(0.187) \\
\end{array}$ \\
\hline PYRET & $\begin{array}{c}0.573 \\
(0.585)\end{array}$ & $\begin{array}{c}0.261 \\
(0.250)\end{array}$ & $\begin{array}{c}0.332 \\
(0.330)\end{array}$ \\
\hline MSTAR $_{\mathrm{t}-1}$ & $\begin{array}{c}4.358 \\
(0.732)\end{array}$ & $\begin{array}{c}3.404 \\
(1.084)\end{array}$ & $\begin{array}{c}3.342 \\
(1.102)\end{array}$ \\
\hline BANK & $\begin{array}{c}0.045 \\
(0.208)\end{array}$ & $\begin{array}{c}0.045 \\
(0.208)\end{array}$ & $\begin{array}{c}0.137 \\
(0.344)\end{array}$ \\
\hline \multirow[t]{2}{*}{$\mathrm{N}$} & 67 & 89 & 2035 \\
\hline & \multicolumn{3}{|c|}{ Broker-sold funds } \\
\hline Variable & Advertised performance & Advertised, but not performance & Did not advertise \\
\hline $\mathrm{FLOW}_{\mathrm{t}}$ & $\begin{array}{c}0.197 \\
(0.315) \\
\end{array}$ & $\begin{array}{c}0.125 \\
(0.550) \\
\end{array}$ & $\begin{array}{c}0.266 \\
(0.712) \\
\end{array}$ \\
\hline FLOW $_{t-1}$ & $\begin{array}{c}0.167 \\
(0.519) \\
\end{array}$ & $\begin{array}{r}0.095 \\
(0.559) \\
\end{array}$ & $\begin{array}{c}0.286 \\
(1.629)\end{array}$ \\
\hline LNASSETS & $\begin{array}{c}7.667 \\
(0.907)\end{array}$ & $\begin{array}{c}6.416 \\
(1.568)\end{array}$ & $\begin{array}{c}5.518 \\
(1.460)\end{array}$ \\
\hline MERGE & $\begin{array}{c}0.0 \\
(0.0) \\
\end{array}$ & $\begin{array}{r}0.047 \\
(0.213) \\
\end{array}$ & $\begin{array}{c}0.041 \\
(0.198) \\
\end{array}$ \\
\hline NETEXP $_{t-1}$ & $\begin{array}{c}0.917 \\
(0.311) \\
\end{array}$ & $\begin{array}{c}1.051 \\
(0.360) \\
\end{array}$ & $\begin{array}{c}1.076 \\
(0.344) \\
\end{array}$ \\
\hline LNMIN & $\begin{array}{c}6.515 \\
(1.716) \\
\end{array}$ & $\begin{array}{c}6.832 \\
(1.080) \\
\end{array}$ & $\begin{array}{c}6.757 \\
(0.741) \\
\end{array}$ \\
\hline NOMIN & $\begin{array}{c}0.053 \\
(0.229) \\
\end{array}$ & $\begin{array}{c}0.023 \\
(0.152) \\
\end{array}$ & $\begin{array}{c}0.001 \\
(0.031) \\
\end{array}$ \\
\hline PYRET & $\begin{array}{c}0.462 \\
(0.396)\end{array}$ & $\begin{array}{c}0.316 \\
(0.305)\end{array}$ & $\begin{array}{c}0.353 \\
(0.331) \\
\end{array}$ \\
\hline MSTAR $_{\mathrm{t}-1}$ & $\begin{array}{c}4.053 \\
(0.780) \\
\end{array}$ & $\begin{array}{r}3.349 \\
(1.193) \\
\end{array}$ & $\begin{array}{c}3.349 \\
(1.106) \\
\end{array}$ \\
\hline BANK & $\begin{array}{c}0.0 \\
(0.0) \\
\end{array}$ & $\begin{array}{c}0.0 \\
(0.0) \\
\end{array}$ & $\begin{array}{c}0.099 \\
(0.298) \\
\end{array}$ \\
\hline \multirow[t]{2}{*}{$\mathrm{N}$} & 19 & 43 & 1074 \\
\hline & \multicolumn{3}{|c|}{ Direct-market funds } \\
\hline Variable & Advertised performance & Advertised, but not performance & Did not advertise \\
\hline $\mathrm{FLOW}_{\mathrm{t}}$ & $\begin{array}{c}0.385 \\
(0.593) \\
\end{array}$ & $\begin{array}{c}-0.060 \\
(0.296) \\
\end{array}$ & $\begin{array}{c}0.212 \\
(0.726) \\
\end{array}$ \\
\hline $\mathrm{FLOW}_{\mathrm{t}-1}$ & $\begin{array}{c}4.206 \\
(20.605)\end{array}$ & $\begin{array}{c}0.053 \\
(0.455) \\
\end{array}$ & $\begin{array}{c}0.283 \\
(2.919) \\
\end{array}$ \\
\hline LNASSETS & $\begin{array}{c}7.309 \\
(1.544) \\
\end{array}$ & $\begin{array}{c}6.557 \\
(1.658) \\
\end{array}$ & $\begin{array}{c}5.612 \\
(1.385) \\
\end{array}$ \\
\hline
\end{tabular}




\begin{tabular}{|c|c|c|c|}
\hline MERGE & 0.021 & 0.0 & 0.041 \\
& $(0.144)$ & $(0.0)$ & $(0.197)$ \\
\hline NETEXP $_{\text {t-1 }}$ & 1.045 & 0.856 & 0.979 \\
& $(0.266)$ & $(0.330)$ & $(0.365)$ \\
\hline LNMIN & 7.778 & 6.762 & 8.763 \\
& $(1.187)$ & $(3.457)$ & $(3.766)$ \\
\hline NOMIN & 0.0 & 0.174 & 0.076 \\
& $(0.0)$ & $(0.383)$ & $0.265)$ \\
\hline PYRET & 0.617 & 0.210 & $(0.328)$ \\
& $(0.644)$ & $(0.173)$ & 3.334 \\
& 4.479 & 3.457 & $(1.097)$ \\
\hline MSTAR & $(0.684)$ & $(0.982)$ & 0.179 \\
& 0.063 & 0.087 & $(0.384)$ \\
\hline BANK & $(0.245)$ & $(0.285)$ & 961 \\
\hline N & 48 & 46 & \\
\hline
\end{tabular}

Standard deviations in parentheses. Variable descriptions can be found in Appendix Table A1.

Table 4. Descriptive statistics: Fixed-income funds

\begin{tabular}{|c|c|c|c|c|c|c|}
\hline & \multicolumn{2}{|c|}{ All funds } & \multicolumn{2}{|c|}{ Broker-sold funds } & \multicolumn{2}{|c|}{ Direct-market funds } \\
\hline Variable & Advertised & $\begin{array}{c}\text { Did not } \\
\text { advertise }\end{array}$ & Advertised & $\begin{array}{c}\text { Did not } \\
\text { advertise }\end{array}$ & Advertised & $\begin{array}{c}\text { Did not } \\
\text { advertise }\end{array}$ \\
\hline $\mathrm{FLOW}_{\mathrm{t}}$ & $\begin{array}{l}-0.123 \\
(0.106)\end{array}$ & $\begin{array}{l}-0.091 \\
(0.360)\end{array}$ & $\begin{array}{l}-0.150 \\
(0.082)\end{array}$ & $\begin{array}{l}-0.127 \\
(0.332)\end{array}$ & $\begin{array}{l}-0.107 \\
(0.116)\end{array}$ & $\begin{array}{l}-0.040 \\
(0.391)\end{array}$ \\
\hline FLOW $_{t-1}$ & $\begin{array}{c}0.425 \\
(3.978)\end{array}$ & $\begin{array}{c}0.700 \\
(24.958)\end{array}$ & $\begin{array}{c}0.007 \\
(0.145)\end{array}$ & $\begin{array}{c}0.101 \\
(2.557)\end{array}$ & $\begin{array}{c}0.671 \\
(5.010)\end{array}$ & $\begin{array}{c}1.559 \\
(38.819)\end{array}$ \\
\hline LNASSETS & $\begin{array}{c}5.791 \\
(1.631)\end{array}$ & $\begin{array}{c}4.678 \\
(1.287)\end{array}$ & $\begin{array}{c}6.113 \\
(1.256)\end{array}$ & $\begin{array}{c}4.504 \\
(1.250)\end{array}$ & $\begin{array}{c}4.927 \\
(1.299)\end{array}$ & $\begin{array}{c}4.927 \\
(1.299)\end{array}$ \\
\hline MERGE & $\begin{array}{c}0.040 \\
(0.198)\end{array}$ & $\begin{array}{c}0.038 \\
(0.191)\end{array}$ & $\begin{array}{c}0.043 \\
(0.206)\end{array}$ & $\begin{array}{c}0.035 \\
(0.183)\end{array}$ & $\begin{array}{c}0.038 \\
(0.194)\end{array}$ & $\begin{array}{c}0.042 \\
(0.201)\end{array}$ \\
\hline NETEXP $_{t-1}$ & $\begin{array}{c}0.560 \\
(0.209)\end{array}$ & $\begin{array}{c}0.704 \\
(0.236)\end{array}$ & $\begin{array}{c}0.641 \\
(0.219)\end{array}$ & $\begin{array}{c}0.731 \\
(0.224)\end{array}$ & $\begin{array}{c}0.513 \\
(0.189)\end{array}$ & $\begin{array}{c}0.665 \\
(0.247)\end{array}$ \\
\hline LNMIN & $\begin{array}{c}7.512 \\
(1.451)\end{array}$ & $\begin{array}{c}7.750 \\
(2.734)\end{array}$ & $\begin{array}{c}6.943 \\
(0.116)\end{array}$ & $\begin{array}{c}6.843 \\
(0.577)\end{array}$ & $\begin{array}{c}7.847 \\
(1.745)\end{array}$ & $\begin{array}{c}9.051 \\
(3.854)\end{array}$ \\
\hline NOMIN & $\begin{array}{c}0.008 \\
(0.090)\end{array}$ & $\begin{array}{c}0.032 \\
(0.176)\end{array}$ & $\begin{array}{c}0.0 \\
(0.0)\end{array}$ & $\begin{array}{c}0.0 \\
(0.0)\end{array}$ & $\begin{array}{c}0.013 \\
(0.113)\end{array}$ & $\begin{array}{c}0.077 \\
(0.267)\end{array}$ \\
\hline PYRET & $\begin{array}{l}-0.018 \\
(0.034)\end{array}$ & $\begin{array}{l}-0.013 \\
(0.048)\end{array}$ & $\begin{array}{l}-0.027 \\
(0.023)\end{array}$ & $\begin{array}{l}-0.021 \\
(0.046)\end{array}$ & $\begin{array}{l}-0.013 \\
(0.038)\end{array}$ & $\begin{array}{l}-0.003 \\
(0.048)\end{array}$ \\
\hline MSTAR $_{\mathrm{t}-1}$ & $\begin{array}{c}3.911 \\
(0.865)\end{array}$ & $\begin{array}{c}3.127 \\
(1.077)\end{array}$ & $\begin{array}{c}3.826 \\
(0.926)\end{array}$ & $\begin{array}{c}2.774 \\
(0.977)\end{array}$ & $\begin{array}{c}3.962 \\
(0.829)\end{array}$ & $\begin{array}{c}3.634 \\
(1.010)\end{array}$ \\
\hline BANK & $\begin{array}{c}0.0 \\
(0.0)\end{array}$ & $\begin{array}{c}0.174 \\
(0.379)\end{array}$ & $\begin{array}{c}0.0 \\
(0.0)\end{array}$ & $\begin{array}{c}0.108 \\
(0.310)\end{array}$ & $\begin{array}{c}0.0 \\
(0.0)\end{array}$ & $\begin{array}{c}0.269 \\
(0.444)\end{array}$ \\
\hline $\mathrm{N}$ & 124 & 1855 & 46 & 1093 & 78 & 762 \\
\hline
\end{tabular}

Standard deviations in parentheses. Variable descriptions can be found in Appendix Table A1. 
Table 5. Pooled estimation of flows on past returns and advertising

\begin{tabular}{|c|c|c|c|c|c|c|c|}
\hline & \multicolumn{3}{|c|}{ Domestic equity } & \multicolumn{3}{|c|}{ All equity } & Fixed income \\
\hline & (1) & (2) & (3) & (1) & (2) & (3) & (1) \\
\hline AD99 & $\begin{array}{l}0.0738 \\
(0.114)\end{array}$ & & $\begin{array}{l}0.0251 \\
(0.592)\end{array}$ & $\begin{array}{c}0.0011 \\
(0.981)\end{array}$ & & $\begin{array}{l}-0.0199 \\
(0.701)\end{array}$ & $\begin{array}{c}0.0258 \\
(0.035)^{b}\end{array}$ \\
\hline APERF & & $\begin{array}{c}0.1351 \\
(0.079)^{\mathrm{c}}\end{array}$ & $\begin{array}{c}0.1117 \\
(0.192)\end{array}$ & & $\begin{array}{l}0.0324 \\
(0.688)\end{array}$ & $\begin{array}{l}0.0510 \\
(0.584)\end{array}$ & \\
\hline $\mathrm{FLOW}_{\mathrm{t}-1}$ & $\begin{array}{c}0.0181 \\
(0.107)^{\mathrm{c}}\end{array}$ & $\begin{array}{c}0.0180 \\
(0.108)^{\mathrm{c}}\end{array}$ & $\begin{array}{c}0.0180 \\
(0.108)^{\mathrm{c}}\end{array}$ & $\begin{array}{l}0.0042 \\
(0.224)\end{array}$ & $\begin{array}{l}0.0040 \\
(0.239)\end{array}$ & $\begin{array}{l}0.0040 \\
(0.239)\end{array}$ & $\begin{array}{l}0.0001 \\
(0.216)\end{array}$ \\
\hline LNASSETS & $\begin{array}{l}-0.1449 \\
(0.000)^{\mathrm{a}}\end{array}$ & $\begin{array}{l}-0.1451 \\
(0.000)^{\mathrm{a}}\end{array}$ & $\begin{array}{l}-0.1456 \\
(0.000)^{\mathrm{a}}\end{array}$ & $\begin{array}{l}-0.1355 \\
(0.000)^{\mathrm{a}}\end{array}$ & $\begin{array}{l}-0.1362 \\
(0.000)^{\mathrm{a}}\end{array}$ & $\begin{array}{l}-0.1358 \\
(0.000)^{\mathrm{a}}\end{array}$ & $\begin{array}{l}-0.0500 \\
(0.000)^{\mathrm{a}}\end{array}$ \\
\hline PYRET(1999) & $\begin{array}{c}1.276 \\
(0.000)^{\mathrm{a}}\end{array}$ & $\begin{array}{c}1.271 \\
(0.000)^{\mathrm{a}}\end{array}$ & $\begin{array}{c}1.271 \\
(0.000)^{\mathrm{a}}\end{array}$ & $\begin{array}{c}0.8913 \\
(0.000)^{\mathrm{a}}\end{array}$ & $\begin{array}{c}0.8896 \\
(0.000)^{\mathrm{a}}\end{array}$ & $\begin{array}{c}0.8895 \\
(0.000)^{\mathrm{a}}\end{array}$ & $\begin{array}{c}1.837 \\
(0.000)^{\mathrm{a}}\end{array}$ \\
\hline PYRET(1998) & $\begin{array}{c}0.4909 \\
(0.002)^{\mathrm{a}}\end{array}$ & $\begin{array}{c}0.4799 \\
(0.003)^{\mathrm{a}}\end{array}$ & $\begin{array}{c}0.4816 \\
(0.003)^{\mathrm{a}}\end{array}$ & $\begin{array}{c}0.4649 \\
(0.000)^{\mathrm{a}}\end{array}$ & $\begin{array}{c}0.4620 \\
(0.000)^{\mathrm{a}}\end{array}$ & $\begin{array}{c}0.4611 \\
(0.000)^{\mathrm{a}}\end{array}$ & $\begin{array}{c}2.538 \\
(0.000)^{\mathrm{a}}\end{array}$ \\
\hline PYRET(1997) & $\begin{array}{c}0.0068 \\
(0.025)^{\mathrm{b}}\end{array}$ & $\begin{array}{c}0.0068 \\
(0.025)^{\mathrm{b}}\end{array}$ & $\begin{array}{c}0.0068 \\
(0.025)^{\mathrm{b}}\end{array}$ & $\begin{array}{c}0.0063 \\
(0.001)^{\mathrm{a}}\end{array}$ & $\begin{array}{c}0.0063 \\
(0.001)^{\mathrm{a}}\end{array}$ & $\begin{array}{c}0.0063 \\
(0.001)^{\mathrm{a}}\end{array}$ & $\begin{array}{l}0.0077 \\
(0.253)\end{array}$ \\
\hline Special Equity & & & & $\begin{array}{l}-0.0020 \\
(0.976)\end{array}$ & $\begin{array}{l}-0.0025 \\
(0.970)\end{array}$ & $\begin{array}{l}-0.0026 \\
(0.969)\end{array}$ & \\
\hline Inter Equity & & & & $\begin{array}{r}-0.0765 \\
(0.111)\end{array}$ & $\begin{array}{l}-0.0764 \\
(0.112)\end{array}$ & $\begin{array}{l}-0.0754 \\
(0.118)\end{array}$ & \\
\hline Intercept & $\begin{array}{c}0.4415 \\
(0.001)^{\mathrm{a}}\end{array}$ & $\begin{array}{c}0.4461 \\
(0.001)^{\mathrm{a}}\end{array}$ & $\begin{array}{c}0.4481 \\
(0.000)^{\mathrm{a}}\end{array}$ & $\begin{array}{c}0.5024 \\
(0.000)^{\mathrm{a}}\end{array}$ & $\begin{array}{c}0.5068 \\
(0.000)^{\mathrm{a}}\end{array}$ & $\begin{array}{c}0.5051 \\
(0.000)^{\mathrm{a}}\end{array}$ & $\begin{array}{c}-0.0353 \\
(0.642)\end{array}$ \\
\hline R-sq. & 0.341 & 0.341 & 0.341 & 0.267 & 0.267 & 0.267 & 0.071 \\
\hline N obs. & 1500 & 1500 & 1500 & 2191 & 2191 & 2191 & 1979 \\
\hline
\end{tabular}

This table presents OLS results from estimating a model of fund flows for the year 2000. Standard errors have been corrected for heteroskedascity and dependence across classes within multiple share class funds as described in Rogers (1993).

'a' Significant at the one percent level; 'b' significant at the five percent level; 'c' significant at the ten percent level. 
Table 6. Estimation of flows on past returns and advertising segregated by load and no-load

\begin{tabular}{|c|c|c|c|c|c|c|c|c|c|c|}
\hline & \multicolumn{4}{|c|}{ Domestic equity } & \multicolumn{4}{|c|}{ All equity } & \multicolumn{2}{|c|}{ Fixed income } \\
\hline & (1 BS) & $(1 \mathrm{DM})$ & $(2 \mathrm{BS})$ & (2 DM) & (1 BS) & $(1 \mathrm{DM})$ & (2 BS) & (2 DM) & (BS) & (DM) \\
\hline AD99 & $\begin{array}{l}0.1765 \\
(0.000)^{\mathrm{a}}\end{array}$ & $\begin{array}{l}0.0338 \\
(0.582)\end{array}$ & $\begin{array}{l}0.1496 \\
(0.021)^{\mathrm{b}}\end{array}$ & $\begin{array}{l}-0.0431 \\
(0.431)\end{array}$ & $\begin{array}{l}0.0633 \\
(0.377)\end{array}$ & $\begin{array}{l}-0.0275 \\
(0.637)\end{array}$ & $\begin{array}{l}0.0714 \\
(0.447)\end{array}$ & $\begin{array}{l}-0.0998 \\
(0.048)^{\mathrm{b}}\end{array}$ & $\begin{array}{l}0.0669 \\
(0.001)^{\mathrm{a}}\end{array}$ & $\begin{array}{l}-0.0241 \\
(0.241)\end{array}$ \\
\hline APERF & & & $\begin{array}{l}0.0698 \\
(0.402)\end{array}$ & $\begin{array}{l}0.1691 \\
(0.131)\end{array}$ & & & $\begin{array}{l}-0.0268 \\
(0.829)\end{array}$ & $\begin{array}{l}0.1506 \\
(0.153)\end{array}$ & & \\
\hline FLOW $_{\mathrm{t}-1}$ & $\begin{array}{l}0.0635 \\
(0.065)^{\mathrm{c}}\end{array}$ & $\begin{array}{l}0.0103 \\
(0.182)\end{array}$ & $\begin{array}{l}0.0636 \\
(0.065)^{\mathrm{c}}\end{array}$ & $\begin{array}{l}0.0101 \\
(0.186)\end{array}$ & $\begin{array}{l}0.0396 \\
(0.066)^{\mathrm{c}}\end{array}$ & $\begin{array}{l}0.0016 \\
(0.443)\end{array}$ & $\begin{array}{l}0.0395 \\
(0.066)^{\mathrm{c}}\end{array}$ & $\begin{array}{l}0.0012 \\
(0.553)\end{array}$ & $\begin{array}{l}0.0014 \\
(0.542)\end{array}$ & $\begin{array}{l}0.0000 \\
(0.917)\end{array}$ \\
\hline LNASSETS & $\begin{array}{l}-0.1532 \\
(0.000)^{\mathrm{a}}\end{array}$ & $\begin{array}{l}-0.1356 \\
(0.000)^{\mathrm{a}}\end{array}$ & $\begin{array}{l}-0.1534 \\
(0.000)^{\mathrm{a}}\end{array}$ & $\begin{array}{l}-0.1372 \\
(0.000)^{\mathrm{a}}\end{array}$ & $\begin{array}{l}-0.1455 \\
(0.000)^{\mathrm{a}}\end{array}$ & $\begin{array}{l}-0.1222 \\
(0.000)^{\mathrm{a}}\end{array}$ & $\begin{array}{l}-0.1454 \\
(0.000)^{\mathrm{a}}\end{array}$ & $\begin{array}{l}-0.1236 \\
(0.000)^{\mathrm{a}}\end{array}$ & $\begin{array}{l}-0.0597 \\
(0.000)^{\mathrm{a}}\end{array}$ & $\begin{array}{l}-0.0438 \\
(0.000)^{\mathrm{a}}\end{array}$ \\
\hline $\begin{array}{l}\text { PYRET } \\
(1999)\end{array}$ & $\begin{array}{l}1.307 \\
(0.000)^{\mathrm{a}}\end{array}$ & $\begin{array}{l}1.242 \\
(0.000)^{\mathrm{a}}\end{array}$ & $\begin{array}{l}1.307 \\
(0.000)^{\mathrm{a}}\end{array}$ & $\begin{array}{l}1.228 \\
(0.000)^{\mathrm{a}}\end{array}$ & $\begin{array}{l}0.9249 \\
(0.000)^{\mathrm{a}}\end{array}$ & $\begin{array}{l}0.8409 \\
(0.000)^{\mathrm{a}}\end{array}$ & $\begin{array}{l}0.9251 \\
(0.000)^{\mathrm{a}}\end{array}$ & $\begin{array}{l}0.8312 \\
(0.000)^{\mathrm{a}}\end{array}$ & $\begin{array}{l}2.2196 \\
(0.000)^{\mathrm{a}}\end{array}$ & $\begin{array}{l}0.5690 \\
(0.375)\end{array}$ \\
\hline $\begin{array}{l}\text { PYRET } \\
(1998)\end{array}$ & $\begin{array}{l}0.4962 \\
(0.029)^{\mathrm{b}}\end{array}$ & $\begin{array}{l}0.4123 \\
(0.047)^{b}\end{array}$ & $\begin{array}{l}0.4906 \\
(0.033)^{\mathrm{b}}\end{array}$ & $\begin{array}{l}0.3992 \\
(0.055)^{\mathrm{b}}\end{array}$ & $\begin{array}{l}0.4378 \\
(0.004)^{\mathrm{a}}\end{array}$ & $\begin{array}{l}0.4228 \\
(0.012)^{\mathrm{b}}\end{array}$ & $\begin{array}{l}0.4400 \\
(0.005)^{\mathrm{a}}\end{array}$ & $\begin{array}{l}0.4120 \\
(0.015)^{\mathrm{b}}\end{array}$ & $\begin{array}{l}2.657 \\
(0.000)^{\mathrm{a}}\end{array}$ & $\begin{array}{l}1.439 \\
(0.081)^{\mathrm{c}}\end{array}$ \\
\hline $\begin{array}{l}\text { PYRET } \\
(1997)\end{array}$ & $\begin{array}{l}0.0055 \\
(0.160)\end{array}$ & $\begin{array}{l}0.0071 \\
(0.128)\end{array}$ & $\begin{array}{l}0.0056 \\
(0.158)\end{array}$ & $\begin{array}{l}0.0070 \\
(0.136)\end{array}$ & $\begin{array}{l}0.0066 \\
(0.009)^{\mathrm{a}}\end{array}$ & $\begin{array}{l}0.0058 \\
(0.034)^{\mathrm{b}}\end{array}$ & $\begin{array}{l}0.0066 \\
(0.010)^{\mathrm{a}}\end{array}$ & $\begin{array}{l}0.0058 \\
(0.035)^{\mathrm{b}}\end{array}$ & $\begin{array}{l}0.0173 \\
(0.000)^{\mathrm{a}}\end{array}$ & $\begin{array}{l}0.0004 \\
(0.971)\end{array}$ \\
\hline $\begin{array}{l}\text { Special } \\
\text { Equity }\end{array}$ & & & & & $\begin{array}{l}-0.0138 \\
(0.879)\end{array}$ & $\begin{array}{l}0.0272 \\
(0.771)\end{array}$ & $\begin{array}{l}-0.0134 \\
(0.882)\end{array}$ & $\begin{array}{l}0.0254 \\
(0.785)\end{array}$ & & \\
\hline Inter Equity & & & & & $\begin{array}{l}-0.0991 \\
(0.119)\end{array}$ & $\begin{array}{l}-0.0600 \\
(0.385)\end{array}$ & $\begin{array}{l}-0.0268 \\
(0.119)\end{array}$ & $\begin{array}{l}-0.0610 \\
(0.377)\end{array}$ & & \\
\hline Intercept & $\begin{array}{l}0.5029 \\
(0.001)^{\mathrm{a}}\end{array}$ & $\begin{array}{l}0.3966 \\
(0.032)^{b}\end{array}$ & $\begin{array}{l}0.5039 \\
(0.003)^{\mathrm{a}}\end{array}$ & $\begin{array}{l}0.4142 \\
(0.027)^{b}\end{array}$ & $\begin{array}{l}0.5417 \\
(0.000)^{\mathrm{a}}\end{array}$ & $\begin{array}{l}0.4539 \\
(0.001)^{\mathrm{a}}\end{array}$ & $\begin{array}{l}0.5412 \\
(0.000)^{\mathrm{a}}\end{array}$ & $\begin{array}{l}0.4675 \\
(0.001)^{\mathrm{a}}\end{array}$ & $\begin{array}{l}-0.0908 \\
(0.199)\end{array}$ & $\begin{array}{l}0.0848 \\
(0.567)\end{array}$ \\
\hline R-sq. & 0.401 & 0.296 & 0.401 & 0.297 & 0.301 & 0.239 & 0.301 & 0.240 & 0.104 & 0.040 \\
\hline $\mathrm{N}$ obs. & 739 & 761 & 739 & 761 & 1136 & 1055 & 1136 & 1055 & 1139 & 840 \\
\hline
\end{tabular}

This table presents OLS results from estimating a model of fund flows for the year 2000 independently for broker-sold (BS) and direct-marketed (DM) funds. Standard errors have been corrected for heteroskedascity and dependence across classes within multiple share class funds as described in Rogers (1993).

'a' Significant at the one percent level; 'b' significant at the five percent level; 'c' significant at the ten percent level. 
Table 7. Effect of advertising on net asset flows: full model

\begin{tabular}{|c|c|c|c|c|c|c|}
\hline & \multicolumn{2}{|c|}{ Domestic equity } & \multicolumn{2}{|c|}{ All equity } & \multicolumn{2}{|c|}{ Fixed income } \\
\hline Variable & (BS) & (DM) & (BS) & (DM) & (BS) & (DM) \\
\hline AD99 & $\begin{array}{c}0.1550 \\
(0.018)^{b}\end{array}$ & $\begin{array}{l}-0.1767 \\
(0.003)^{\mathrm{a}}\end{array}$ & $\begin{array}{l}0.0760 \\
(0.325)\end{array}$ & $\begin{array}{l}-0.1970 \\
(0.001)^{\mathrm{a}}\end{array}$ & $\begin{array}{l}0.0309 \\
(0.351)\end{array}$ & $\begin{array}{l}-0.0648 \\
(0.029)^{b}\end{array}$ \\
\hline APERF & $\begin{array}{c}0.0290 \\
(0.717)\end{array}$ & $\begin{array}{c}0.2102 \\
(0.068)^{c}\end{array}$ & $\begin{array}{r}-0.0777 \\
(0.464)\end{array}$ & $\begin{array}{c}0.1825 \\
(0.084)^{\mathrm{c}}\end{array}$ & & \\
\hline $\mathrm{FLOW}_{\mathrm{t}-1}$ & $\begin{array}{c}0.0540 \\
(0.068)^{\mathrm{c}}\end{array}$ & $\begin{array}{c}0.0051 \\
(0.469)\end{array}$ & $\begin{array}{c}0.0381 \\
(0.058)^{\mathrm{c}}\end{array}$ & $\begin{array}{r}0.0025 \\
(0.242)\end{array}$ & $\begin{array}{c}0.0020 \\
(0.424)\end{array}$ & $\begin{array}{r}-0.0001 \\
(0.642)\end{array}$ \\
\hline MERGE & $\begin{array}{c}0.3512 \\
(0.050)^{b}\end{array}$ & $\begin{array}{c}0.3889 \\
(0.000)^{\mathrm{a}}\end{array}$ & $\begin{array}{c}0.2253 \\
(0.090)^{\mathrm{c}}\end{array}$ & $\begin{array}{c}0.2909 \\
(0.001)^{\mathrm{a}}\end{array}$ & $\begin{array}{c}0.5544 \\
(0.002)^{\mathrm{a}}\end{array}$ & $\begin{array}{c}0.3287 \\
(0.000)^{\mathrm{a}}\end{array}$ \\
\hline LNAGE & $\begin{array}{c}0.0121 \\
(0.683) \\
\end{array}$ & $\begin{array}{r}-0.0103 \\
(0.756) \\
\end{array}$ & $\begin{array}{r}-0.0085 \\
(0.733) \\
\end{array}$ & $\begin{array}{l}-0.0481 \\
(0.095)^{\mathrm{c}}\end{array}$ & $\begin{array}{c}0.0181 \\
(0.504) \\
\end{array}$ & $\begin{array}{l}-0.0552 \\
(0.053)^{b}\end{array}$ \\
\hline NETEXP $_{\mathrm{t}-1}$ & $\begin{array}{l}0.0374 \\
(0.794)\end{array}$ & $\begin{array}{l}0.0936 \\
(0.372)\end{array}$ & $\begin{array}{l}0.0672 \\
(0.507)\end{array}$ & $\begin{array}{l}0.0918 \\
(0.250)\end{array}$ & $\begin{array}{c}-0.0285 \\
(0.660)\end{array}$ & $\begin{array}{l}-0.0970 \\
(0.074)^{\mathrm{c}}\end{array}$ \\
\hline LNMIN & $\begin{array}{r}0.0026 \\
(0.946) \\
\end{array}$ & $\begin{array}{l}-0.0261 \\
(0.005)^{\mathrm{a}}\end{array}$ & $\begin{array}{c}-0.0209 \\
(0.515)\end{array}$ & $\begin{array}{l}-0.0134 \\
(0.075)^{\mathrm{c}}\end{array}$ & $\begin{array}{l}-0.0422 \\
(0.125)\end{array}$ & $\begin{array}{c}0.0023 \\
(0.672)\end{array}$ \\
\hline NOMIN & $\begin{array}{l}0.1528 \\
(0.567)\end{array}$ & $\begin{array}{l}-0.2465 \\
(0.074)^{\mathrm{c}}\end{array}$ & $\begin{array}{l}0.4580 \\
(0.168)\end{array}$ & $\begin{array}{c}-0.1090 \\
(0.322)\end{array}$ & & $\begin{array}{l}0.0750 \\
(0.282)\end{array}$ \\
\hline LNASSETS & $\begin{array}{c}-0.1994 \\
(0.000)^{\mathrm{a}}\end{array}$ & $\begin{array}{l}-0.2033 \\
(0.000)^{\mathrm{a}}\end{array}$ & $\begin{array}{l}-0.1793 \\
(0.000)^{\mathrm{a}}\end{array}$ & $\begin{array}{l}-0.1744 \\
(0.000)^{\mathrm{a}}\end{array}$ & $\begin{array}{l}-0.0629 \\
(0.000)^{\mathrm{a}}\end{array}$ & $\begin{array}{l}-0.0589 \\
(0.000)^{\mathrm{a}}\end{array}$ \\
\hline LNFAMASS & $\begin{array}{c}0.0658 \\
(0.006)^{\mathrm{a}}\end{array}$ & $\begin{array}{c}0.0980 \\
(0.000)^{\mathrm{a}}\end{array}$ & $\begin{array}{c}0.0659 \\
(0.000)^{\mathrm{a}}\end{array}$ & $\begin{array}{c}0.0842 \\
(0.000)^{\mathrm{a}}\end{array}$ & $\begin{array}{c}-0.0026 \\
(0.808)\end{array}$ & $\begin{array}{c}0.0244 \\
(0.002)^{\mathrm{a}}\end{array}$ \\
\hline PYRET99 & $\begin{array}{c}0.9708 \\
(0.000)^{\mathrm{a}}\end{array}$ & $\begin{array}{c}1.101 \\
(0.000)^{\mathrm{a}}\end{array}$ & $\begin{array}{c}0.5863 \\
(0.000)^{\mathrm{a}}\end{array}$ & $\begin{array}{c}0.6089 \\
(0.000)^{\mathrm{a}}\end{array}$ & $\begin{array}{c}2.021 \\
(0.004)^{\mathrm{a}}\end{array}$ & $\begin{array}{c}-0.5958 \\
(0.696)\end{array}$ \\
\hline PYRET98 & $\begin{array}{c}0.0638 \\
(0.828)\end{array}$ & $\begin{array}{l}0.2126 \\
(0.522)\end{array}$ & $\begin{array}{c}-0.2141 \\
(0.275)\end{array}$ & $\begin{array}{r}-0.1139 \\
(0.628)\end{array}$ & $\begin{array}{c}2.299 \\
(0.002)^{\mathrm{a}}\end{array}$ & $\begin{array}{l}0.1676 \\
(0.919)\end{array}$ \\
\hline PYRET97 & $\begin{array}{c}0.0004 \\
(0.914)\end{array}$ & $\begin{array}{c}0.0078 \\
(0.171)\end{array}$ & $\begin{array}{r}-0.0003 \\
(0.917)\end{array}$ & $\begin{array}{c}0.0011 \\
(0.749)\end{array}$ & $\begin{array}{c}0.0157 \\
(0.005)^{\mathrm{a}}\end{array}$ & $\begin{array}{r}-0.0042 \\
(0.745)\end{array}$ \\
\hline MSTAR $_{\mathrm{t}-1}$ & $\begin{array}{c}0.1394 \\
(0.003)^{\mathrm{a}}\end{array}$ & $\begin{array}{l}0.0648 \\
(0.247)\end{array}$ & $\begin{array}{c}0.1841 \\
(0.000)^{\mathrm{a}}\end{array}$ & $\begin{array}{c}0.1403 \\
(0.001)^{\mathrm{a}}\end{array}$ & $\begin{array}{c}0.0282 \\
(0.005)^{\mathrm{a}}\end{array}$ & $\begin{array}{c}0.0206 \\
(0.370)\end{array}$ \\
\hline MKTFEE & $\begin{array}{l}0.0096 \\
(0.887)\end{array}$ & $\begin{array}{r}-0.0581 \\
(0.403)\end{array}$ & $\begin{array}{l}0.0205 \\
(0.773)\end{array}$ & $\begin{array}{c}-0.0380 \\
(0.512)\end{array}$ & $\begin{array}{r}-0.0207 \\
(0.511)\end{array}$ & $\begin{array}{c}0.0196 \\
(0.681)\end{array}$ \\
\hline BANK & $\begin{array}{l}-0.1445 \\
(0.022)^{b}\end{array}$ & $\begin{array}{l}-0.1058 \\
(0.040)^{b}\end{array}$ & $\begin{array}{l}-0.1039 \\
(0.099)^{\mathrm{c}}\end{array}$ & $\begin{array}{l}-0.0749 \\
(0.096)^{\mathrm{c}}\end{array}$ & $\begin{array}{c}-0.0368 \\
(0.207)\end{array}$ & $\begin{array}{l}0.0274 \\
(0.304)\end{array}$ \\
\hline MS & $\begin{array}{c}-0.0589 \\
(0.369)\end{array}$ & $\begin{array}{r}-0.0127 \\
(0.797)\end{array}$ & $\begin{array}{c}0.0258 \\
(0.671)\end{array}$ & $\begin{array}{l}-0.0810 \\
(0.055)^{\mathrm{c}}\end{array}$ & $\begin{array}{r}-0.0171 \\
(0.651)\end{array}$ & $\begin{array}{r}-0.0351 \\
(0.164)\end{array}$ \\
\hline $\begin{array}{c}\text { Inv. } \\
\text { Objective }\end{array}$ & No & No & Yes & Yes & Yes & Yes \\
\hline Constant & $\begin{array}{c}-0.2495 \\
(0.507)\end{array}$ & $\begin{array}{c}-0.2420 \\
(0.484)\end{array}$ & $\begin{array}{c}-0.2085 \\
(0.456)\end{array}$ & $\begin{array}{r}-0.0732 \\
(0.779)\end{array}$ & $\begin{array}{l}0.1239 \\
(0.714)\end{array}$ & $\begin{array}{l}0.1575 \\
(0.583)\end{array}$ \\
\hline Adjusted $\mathrm{R}^{2}$ & 0.436 & 0.364 & 0.351 & 0.308 & 0.217 & 0.103 \\
\hline Obs. & 739 & 761 & 1136 & 1055 & 1139 & 840 \\
\hline
\end{tabular}

This table presents OLS results from estimating a model of fund flows for the year 2000 independently for broker-sold (BS) and direct-marketed (DM) funds, segregated into sub-samples of domestic equity, all equity, and fixed income funds. When estimating the model for All Equity and Fixed Income funds, we use indicator variables to control for fund objectives. Results for these variables are not presented to conserve space. Standard errors have been corrected for heteroskedascity and dependence across classes within MS funds as described in Rogers (1993).

'a' Significant at the one percent level; 'b' significant at the five percent level; 'c' significant at the ten percent level. 
Table A1. Description of variables

\begin{tabular}{|c|c|}
\hline AD99 & An indicator variable equal to one if the fund advertised, and zero otherwise. \\
\hline APERF & $\begin{array}{l}\text { An indicator variable equal to one if the fund advertised performance, and zero } \\
\text { otherwise. }\end{array}$ \\
\hline FLOW $_{\mathrm{t}-1}$ & The lagged asset flow from 1999, as calculated in Equation (1). \\
\hline MERGE & An indicator variable equal to one if the fund was the result of a merger during 2000 . \\
\hline LNAGE & The natural logarithm of the fund's age in years since inception. \\
\hline NETEXP $_{t-1}$ & $\begin{array}{l}\text { The fund or class expense ratio, net of its } 12 \mathrm{~b}-1 \text { fee, expressed as a percentage of } \\
\text { assets. }\end{array}$ \\
\hline LNMIN & The natural logarithm of minimum investment amount, if available. \\
\hline NOMIN & $\begin{array}{l}\text { An indicator variable equal to one if the fund did not identify an investment minimum, } \\
\text { and zero otherwise. }\end{array}$ \\
\hline LNASSETS & The natural logarithm of fund or class assets under management as of year-end 1999. \\
\hline LNFAMASS & $\begin{array}{l}\text { The natural logarithm of assets held by the ultimate corporate owner of the fund or } \\
\text { class as of year-end } 1999 \text {. }\end{array}$ \\
\hline PYRET(t-n) & Observations raw return for 1999,1998 , and 1997. \\
\hline MSTAR $_{\mathrm{t}-1}$ & The number of Morningstar stars reported for the fund at year-end 1999. \\
\hline MKTFEE & $\begin{array}{l}\text { An indicator variable equal to one if the fund or class has a } 12 \mathrm{~b}-1 \text { fee and zero } \\
\text { otherwise. }\end{array}$ \\
\hline BANK & $\begin{array}{l}\text { An indicator variable equal to one if the fund is operated by a bank, and zero } \\
\text { otherwise. }\end{array}$ \\
\hline MS & $\begin{array}{l}\text { An indicator variable equal to one if the observation is part of a multiple share class } \\
\text { fund and zero otherwise. }\end{array}$ \\
\hline Fund Objective i & $\begin{array}{l}\text { An indicator variable equal to one if the fund or class is an equity fund in the domestic } \\
\text { equity, special equity or international equity categories when examining equity funds } \\
\text { or government bond, corporate bond, municipal bond, or international bond when } \\
\text { examining fixed income funds, and zero otherwise. }\end{array}$ \\
\hline
\end{tabular}

